Article

\title{
Study of the Relationship between Political Connections and Corporate Re-Entrepreneurial Performance
}

\author{
Zhao Wang *, Xiaobing Liu and Qinhua Liu \\ Faculty of Management and Economics, Dalian University of Technology, Dalian 116024, China \\ * Correspondence: maggie8133@mail.dlut.edu.cn
}

Received: 24 June 2019; Accepted: 23 July 2019; Published: 25 July 2019

check for updates

\begin{abstract}
Based on both resource-based theory and institution-based theory, this study places political connections, acquisition of entrepreneurial resources, institutional environment, and corporate re-entrepreneurial performance into the same research framework. Using data from 223 real estate companies in China as a sample and with the help of the statistical tools SPSS 22.0 and Mplus 7.0, the study examines the internal influence mechanism of political connections on corporate re-entrepreneurial performance as well as the mediating effect of acquisition of entrepreneurial resources and the moderating effect of institutional environment. The empirical results show that both explicit political connections and implicit ones have positive impacts on corporate re-entrepreneurial performance through the mediating effect of acquisition of entrepreneurial knowledge resources and entrepreneurial asset resources. Meanwhile, institutional environment positively regulates the relationship between political connections and corporate re-entrepreneurial performance. The results of the study suggest that political connections have positive impacts on corporate re-entrepreneurial performance under the circumstances of China's transitional economy, but the impacts are restricted by institutional environment to a large extent.
\end{abstract}

Keywords: political connections; entrepreneurial resource acquisition; re-entrepreneurship; institutional environment; corporate performance

\section{Introduction}

Corporate entrepreneurship (CE), as a significant driving force of economic development, has attracted much attention and the research on it has become one of the important subjects in the field of management. Over the past 40 years there have been various concepts of CE, of which the most widely accepted one is that it refers to the entrepreneurial activities conducted by an existing company [1,2] and is an effective combination of entrepreneurship and strategic efforts [3]. $\mathrm{CE}$ encompasses a range of entrepreneurial activities, such as innovation, corporate risk-taking, and strategic renewal [4]. Meanwhile, sustained regeneration, domain redefinition, business model reconstruction, and corporate rejuvenation are also brought in from the perspective of strategic entrepreneurship [5]. It is noticed that these entrepreneurship factors play a vital part in the economic growth of companies [6], which has been verified constantly [7]. Previous studies have shown that $\mathrm{CE}$ helps economic organizations acquire competitive advantages and has a remarkable impact on improving their performance [8-10], and is therefore recognized as an important means of achieving a high level of corporate performance [11]. It is because of the significant role of CE in maintaining and renewing competitive positioning that the study of it is of greater and greater importance [12].

$\mathrm{CE}$ is a complex activity, but few studies have explored it vertically from the perspective of entrepreneurial time and process. Based on time dimension, Zhang et al. divide the entrepreneurial 
activities of a company at different periods of time into initial entrepreneurship and re-entrepreneurship, holding that initial entrepreneurship is a process where entrepreneurs start up a new company for the first time while re-entrepreneurship is a process where an existing company creates new businesses or establishes a new subsidiary company [13]. The former, whose entrepreneurial subject can be either an individual or a team, happens at the stage of establishing a new company while the latter, whose entrepreneurial subject is an existing company, is conducted after the establishment of the company aiming to enter new business fields or start up a new subsidiary company. The different concepts of initial entrepreneurship and re-entrepreneurship have laid theoretical foundations for further exploring the influence factors and the changes of action mechanism in the dynamic process of CE. McEnany et al. think that corporate re-entrepreneurship is a process in which mature companies grow again [14]. He Yongqing et al. hold that re-entrepreneurship is another entrepreneurial behavior of an entrepreneur after suffering a failure of entrepreneurship [15]. They actually define re-entrepreneurship as a new entrepreneurial behavior of an entrepreneur who uses experience and knowledge from the previous entrepreneurial process to implement certain innovation, which is not re-entrepreneurship in the strict sense. Plehn-Dujowich thinks that second entrepreneurship refers to the re-governance and optimization of existing companies' internal power, mechanism and resources [16]. Peng et al., from a capability perspective, give the opinion that second entrepreneurship means existing companies carry out reforms and innovations within themselves and thereby gain development based on the integration and use of resources [17]. From these studies it can be seen that re-entrepreneurship, second entrepreneurship, and even serial entrepreneurship are defined the same in essence, all referring to the behavior of an existing company entering new fields and developing new businesses. Based on the above, we define corporate re-entrepreneurship as a behavior through which existing companies identify and acquire varieties of internal and external new opportunities, improve their core competence and gain another innovative development by integrating all kinds of resources in their process of development.

The 2008 worldwide economic recession as well as the subsequent market globalization and technological advances made the world economic environment become increasingly severe [18] and the global economic development entered a period of continued turmoil, which resulted in the fact that a large number of companies were faced with predicaments and started to use re-entrepreneurial strategies to improve their core competence. In transition economies, especially with China as a representative, this phenomenon emerged endlessly, and big moves kept appearing. The following are a few examples of such companies. China Vanken spent $¥ 79$ billion purchasing the logistics giant GLP (Global Logistic Properties), and Sunac China Holdings Limited became a major shareholder of the hi-tech company LeEco. COFCO (China Oil and Foodstuffs Corporation), established a cooperative relationship with JD in a comprehensive way. Yihua Real Estate abandoned the original business and turned to health and medical treatment. Country Garden began to invest in intelligent robots and modern agriculture.

However, whether entrepreneurship can be successful is determined by many important factors, especially political connections. From the resource-based view, political connections are a kind of heterogeneous resources and have a significant positive correlation with firm performance [19]. Political connections can help companies acquire scarce external resources and conditions such as finance, tax preferences, and government subsidies and promote corporate entrepreneurial behavior through the acquisition of these resources and conditions, which makes them a key factor influencing corporate re-entrepreneurial performance [20]. However, present studies of entrepreneurship in academia are mainly focused on entrepreneurial teams or entrepreneurial opportunities and have achieved abundant results. Few studies are done systematically from a resource perspective [21] and even fewer are about the impacts of political connections as a kind of heterogeneous resources on corporate re-entrepreneurship.

From the perspective of entrepreneurial practice, entrepreneurial environment differs in different countries [22], especially in transition economies and emerging ones. China is a typical transition 
economy, where the economic transformation is basically following the idea of political centralization and economic decentralization [23]. The transition process of China's economy is a process during which market system is established and developed gradually. However, in the process, there is obvious mismatch between the development of product market and that of the factor market, including the market of production factors which consist of human resources, funds, land, and techniques. The development of the production factor market is far behind the product market and the allocation of production factors depends more on the administrative power of the government than on the market mechanism. The Chinese government is loosening regulations of certain industries in its process of marketization. For instance, 'Opinions of the State Council on Encouraging, Supporting and Guiding the Development of Self-employed, Private and Other Non-Public Sectors of the Economy' issued by the State Council of China in 2005 stipulates explicitly that non-public sectors of the economy can enter monopoly industries. However, at present the government still has dominant power over the allocation of production factors during the transition process of China's economy. For one thing, the government is in control of large quantities of production factors; for another, it can intervene the allocation of production factors by administrative means and tends to allocate the productions factors to state-owned enterprises [24]. Therefore, a variety of companies, especially private ones, will seek to establish political connections to mitigate unfavorable impacts of the external environment through political participation or by employing former government officials as corporate senior executives, which is actually a rational response to the current political and economic environment where they lie. Li et al. also hold that political connections are more important in transition economies such as China and Brazil than in other mature economies. Keeping a close relationship with the government helps companies avoid functional incapability in market and institutions in transition economies and emerging ones [25], where political connections play a vital role in entrepreneurial activities as a bond between companies and the government. Accordingly, it is becoming increasingly important to study entrepreneurship, especially corporate re-entrepreneurship, from the perspective of political connections. However, a review of literature has found very little about it. Meanwhile, from the institution-based view, political connections, which are considered to be an informal institution [26] as well as a nonmarket means of resource allocation, have profound and lasting impacts on corporate performance. However, as an informal institution, political connections are inevitably affected and regulated by institutional environment [27], which means that the moderating role of institutional environment deserves much attention when studying the relationship between political connections and corporate re-entrepreneurial performance.

Considering the above, the study concentrates on the political connections and external environment of re-entrepreneurial companies and investigates empirically the internal influence mechanism of political connections, which are divided into explicit and implicit ones, on corporate re-entrepreneurial performance on the basis of the data from some real estate companies in China. The moderating effect of institutional environment on the relationship between political connections and corporate re-entrepreneurial performance is also to be further verified.

The remainder of this paper is structured as follows: Section 2 introduces a literature review and hypotheses; Section 3 describes the research design, followed by empirical results and analyses in Section 4; Section 5 presents the conclusions and management implications.

\section{Literature Review and Hypotheses}

\subsection{Literature Review}

\subsubsection{Political Connections}

Plenty of facts and research have shown that political connections are ubiquitous all over the world, especially in emerging market countries and developing ones [28]. Earlier research on political connections found that entrepreneurs expend time, effort, and resources in establishing relationships with government officials with the intention of gaining benefit for their companies [29]. 
The term 'political connections' was first used formally in Fisman's Estimating the Value of Political Connections [30]. By studying more than 20,000 companies from 47 countries, Faccio pointed out that if one of the shareholders or senior executives of a company is among senior government officials or members of congress or has a close relationship with senior government officials, then the company is politically connected [28]. This elaboration has become a research model of the definition of political connections and later relevant research is mostly based on it. For example, Goldman et al. think that if board members of a company have political background, then the company is considered politically connected [31]. Schoenherr believes that a company is considered to have political connections if its CEO is either a graduate from Korea University Business Administration where the then President of South Korea Lee Myung Bak used to study or a former executive of Hyundai Engineering and Construction where Lee used to work [32]. Whereas, $\mathrm{Xu}$ et al. summarize political connections as the relationship between companies and the government [33]. Previous research has shown that fierce market competition helps companies establish political connections [34], which are intangible resources that have positive and long-term impacts on corporate wealth [35] and therefore greatly affect corporate performance [36].

\subsubsection{Corporate Re-Entrepreneurial Performance}

Entrepreneurial performance demonstrates the overall results of entrepreneurial activities [37] and measures the extent to which an organization has achieved its entrepreneurial objectives [38]. It is about the improvement and achievement of organizational competitive advantages [39]. Entrepreneurial performance and re-entrepreneurial performance have much in common and some of their influence factors are also similar [15], so scholars often use for reference or adopt the research theories and measurement methods of entrepreneurial performance when studying re-entrepreneurial performance [40]. At present, studies of entrepreneurial performance are mainly based on four theories, the population ecology theory, the social cognition theory, the resource-based theory and the strategic adaptation theory [41]. The population ecology theory holds that the survival of companies depends on environmental changes and companies' capability to adapt to the changes. The social cognition theory believes that the survival of entrepreneurial companies depends on the motivation and behavior of entrepreneurs. The resource-based view emphasizes at the company level the great importance of available external and internal resources to the survival and development of companies. The strategic adaptation view avers that both the environment and entrepreneurial strategies are vital influence factors of entrepreneurial performance. Based on their own understanding of entrepreneurial performance, scholars conducted their studies from different perspectives and had different results and different ideas, especially in the core measurement indexes and measurement methods of entrepreneurial performance.

The main measurement indexes of entrepreneurial performance are short-term and long-term indexes, indexes of growth and profitability, and financial and non-financial indexes [42]. The most widely used ones are financial and non-financial indexes, which can reflect entrepreneurial performance in a more integrated way. Based on this indicator system, many scholars have developed measurement scales and conducted empirical research. However, these indexes mostly involve corporate trade secrets, which means that it is hard to obtain the key data and ensure their accuracy as well. As a result, more and more research introduces subjective measurement methods as a supplement to objective data in combination with practical situation [43]. Previous studies have confirmed that subjective measurement results and objective ones are highly consistent [44]. A review of literature on entrepreneurial performance showed that the typical assessment methodologies used most at present are objective and subjective assessment methods as well as absolute and relative ones [45]. According to the different development phases of companies and their practical situation, scholars selected different assessment methods and measurement indexes and formed different assessment systems in accordance with their research needs. No matter what indicator system is used, it is of practical value on condition that it can reflect pivotal information which is needed for a research. 


\subsubsection{Political Connections and Corporate Re-Entrepreneurial Performance}

The impacts of political connections on corporate performance has been a topic of interest for scholars and is exactly what the academic significance of political connections lies in. Literature studies show that companies with favorable political connections have better performance compared with companies with less favorable ones. For example, Liedong confirmed the benefits that political connections can bring to corporate performance through a systematic study of 56 documents [46]. By studying the sample non-financial companies listed in the Tunisian Stock Exchange, Maaloul et al. found that political connections help improve corporate performance and value [47]. Lee et al. found, by analyzing data set collected from some Chinese companies, that political connections are beneficial to the improvement of corporate innovation performance [48]. Cheng et al. also hold similar opinions [49]. Moreover, political connections play a positive part in such aspects as helping companies obtain bank loans, improve stock performance and increase corporate value [50-53]. Most of the pertinent literature found positive correlation between political connections and corporate performance, but some reached quite opposite conclusions. For instance, Pan et al. found that political connections lead to improper allocation of capital and thereby deteriorate corporate performance [54]. Research by Zhang et al. indicated that the stock returns and corporate performance of companies with favorable political connections decrease after they go public [55]. Hadani et al. found that companies' political investment and market performance are negatively correlated and that accumulated political investment worsens market and financial performance [56]. Still, there is a minority of literature showing that political connections have no or a mixture of good and bad impacts on corporate performance. For example, Hersch et al. found that there is no conspicuous positive correlation between political connections and corporate performance. Research by Lee et al. suggested that appointing local government officials as company directors can increase the stock price collapse risk of state-controlled listed companies whereas employing politicians as company directors helps decrease the stock price collapse risk of private listed companies [57]. In conclusion, there are still great disagreements among scholars about whether political connections can improve corporate performance.

Corporate re-entrepreneurship is an important means of improving corporate performance, but there are only a few studies on its relationship to political connections, among which are the ones of Peng et al. and He et al. Peng et al. found that an increase in the entrepreneurship policy support has a positive impact on the entrepreneurial performance of corporate second entrepreneurship by studying 30 companies typically representative of traditional industries [17]. However, they did not deeply explore the influence mechanism between the two. He et al. analyzed ten large private companies in China by applying a multi-case study method and found that policy factors are important to corporate re-entrepreneurial performance, but they can only influence it by acting on other factors first, among which resource acquisition plays an intermediary role. This literature provides a new idea for research into the relationship between political factors and corporate re-entrepreneurship. However, it is a case study and cannot verify in detail the internal mechanism among political connections, resource acquisition and corporate re-entrepreneurial performance, and the results of the study are not universal. Political connections, which have been basically recognized in academia as a means of acquiring resources, are considered to be a significant factor in the survival and performance improvement of emerging economic organizations. They can help economic organizations acquire key information and resources to buffer uncertainty and gain competitive advantages [58]. According to the resource-based theory, these resources are exactly the important drivers of corporate re-entrepreneurial performance.

\subsubsection{Entrepreneurial Resource Acquisition}

Entrepreneurial resources, which include the resources invested and used after the establishment of a company as well as those obtained before and during the entrepreneurial process, have drawn much attention in academia as a crucial influence factor in entrepreneurial activities. Caves pointed out at an earlier time that all resources that meet the demands of entrepreneurial activities are entrepreneurial resources [59]. Barney avers that entrepreneurial resources are a key condition that new enterprises 
must possess or can use when they struggle to survive and develop in the competitive market [60]. Grande defines entrepreneurial resources as a kind of unique resources which can help promote competitiveness and create value for entrepreneurial enterprises [61].

The acquisition of entrepreneurial resources is a dynamic process where companies or individual entrepreneurs obtain entrepreneurial resources [62], which is also supported by Sirmon, Hitt, and Ireland in their studies [63]. From the resource-based perspective, the chances of enterprises' achieving success in entrepreneurship will increase greatly if they can manage and integrate the acquired resources in high efficiency during the entrepreneurial process [64]. Nevertheless, it is extremely difficult to obtain funds and other external resources for most entrepreneurial companies [65], which are always faced with great external uncertainty in their efforts to acquire entrepreneurial resources [66]. A review of literature showed that it has become entrepreneurial companies' first choice to take advantage of their social network relationships to overcome the challenge of acquiring external resources. Existing literature has also confirmed the positive role of social network relationships in entrepreneurial companies' acquisition of external resources [67]. Relevant research also indicates that extensive social networks can enhance the capability of entrepreneurial companies to acquire external resources [68]. Such a network relationship enables outside investors to get more information about entrepreneurial investment opportunities and thereby decrease information asymmetry [69]. In addition, a reliable social network relationship endows entrepreneurial companies with good reputation, which means that entrepreneurial companies possess positive features associated with high quality. As a typical social network relationship [70], the unique role of political connections in promoting the acquisition of external resources has been verified in abundance [36], which makes political connections a significant influence factor that companies must take into consideration when implementing entrepreneurship [71].

Lots of studies on the relationship between entrepreneurial resource acquisition and entrepreneurial performance have found that the former has positive impacts on the latter [72]. Still, some scholars found that different categories of corporate entrepreneurial resources have different impacts on entrepreneurial performance [73]. Competitive heterogeneous resources that a company has over its competitors help improve corporate performance [74].

\subsubsection{Institutional Environment}

The institutional environment where a company lies when implementing entrepreneurship has also been concerned by scholars in the empirical study of entrepreneurial performance. As a momentous factor influencing the operation and development of companies, institutional environment is always in dynamic change, in which there exist both threats and opportunities [75]. Market and environmental vitality restricted and affected by institutional environment have become important factors influencing entrepreneurial activities in small and medium-sized companies [76]. Institutional environment can impact a company's strategic action [77] and regulate the relationship between risk-taking and performance in the entrepreneurship orientation [78]. Judging from the current situation of economic development, it can be seen that the political environment in most countries is uncertain with lots of influence factors and rapid changes, which will easily undermine the competitive advantages of economic organizations established through their original resource conditions and capabilities of organization and management. Therefore, economic organizations must respond quickly to changes in the outside world and adjust their resource allocation and strategic decisions in good time.

\subsection{Research Hypotheses}

\subsubsection{Political Connections and Entrepreneurial Resource Acquisition}

Presently, companies in each country mainly obtain political connections in the following ways: 1. Key figures such as corporate shareholders, senior executives, and board members have or used to have certain political statuses. For example, they are or used to be former government officials or 
members of congress. 2. Companies make political donations to candidates in political campaigns [79]. 3. Companies hold a certain proportion of state-owned shares [80]. 4. Major shareholders, senior executives or board members of companies have personal relations with government officials or members of congress, or their friends, or relatives serve in government departments. 5. Companies employ as consultants organizations or individuals that can have an impact on government decisions [81]. The former three correlations are explicit and easy to be observed while the latter two are implicit. Wang Zhenyi found that political connections are a special government-enterprise relationship, which may be explicit or implicit [82]. Based on this, we divide political connections into explicit ones and implicit ones.

China has a special political system, which makes it different from other countries. In 2001, the Central Committee of the Communist Party of China issued 'Provisions on Individual Businesses Run by Spouses and Children of Major Leading Cadres of the Party Committee and the Government at the Provincial and Prefectural Levels (for Trial Implementation)', which has specific prohibitions on the business behavior of government officials and their family members and explicitly stipulates that the spouses and children of the major leading cadres of the party committee and the government at the provincial and prefectural levels mustn't engage in any business activities that are within the power of the leading cadres. Under such a system of political supervision, it is almost impossible to establish political connections in the way that the government officials themselves or their family members become shareholders or senior executives of private companies. On the contrary, the political background or political status of corporate senior executives (e.g., being deputies to China's People's Congress or members of the Chinese People's Political Consultative Conference (CPPCC)) and the close personal relationships between them and government officials have been a primary form of establishing political connections.

Entrepreneurial resources, as a sum of all kinds of resources possessed by companies in the entrepreneurial process, are pivotal to corporate entrepreneurship and growth. Political connections as an important network capability greatly impact the entrepreneurial resource acquisition of companies [83]. Based on the study of the existing relevant literature, we can find that political connections can bring companies the following economic values. First, they can help companies obtain information which is usually available to the insiders, precisely know in advance the changes of policies and potential market orientation in the future and thereby identify valuable entrepreneurial opportunities. Second, it is easier for companies with political connections to get tax preferences and government subsidies than those without political connections [84,85]. As Faccio's transnational research confirmed, companies with political connections can enjoy preferential tax rates. Third, political connections can help companies obtain favorable financing conditions and reduce financing constraints [86,87]. Finally, they can assist companies to break governmental regulatory barriers [88]. The government can affect varieties, numbers and distribution of entrepreneurial opportunities by deregulating certain industries and developing plans for them [89] whereas political connections, in turn, can help companies save cost and acquire significant resources and privileges by influencing government supervision and policy environment [90]. In China, political connections, which have some of the functions of legal institutions, have become an important means of companies' seeking and developing favorable relationships with the government or government officials. Companies can acquire protection and resources which are hard to obtain from other channels by seeking and developing advantageous explicit political connections and implicit ones [91]. A large quantity of these resources and protection are hard to obtain in a fair way through the price mechanism of the market and an even smaller part of them are impossible to acquire because of the strict control of the government. However, these resources are vital factors which determine whether corporate entrepreneurship can be successful or not. For instance, the Chinese government still has authority over economic resources such as credit funds, in which case political connections can help companies acquire financial resources and improve the levels of government subsidies [92]. Meanwhile, political connections have the function of supervising the government in the way that corporate senior executives' participation in 
the administration and discussion of government affairs helps prevent the government from infringing the property rights of private companies.

Based on the study of $\mathrm{Zhu}$ and $\mathrm{Li}$, we divide the various entrepreneurial resources that political connections can bring to companies into entrepreneurial asset ones and entrepreneurial knowledge ones [93]. By asset resources we mainly refer to the tangible assets companies invest to implement entrepreneurship, including human resources, funds, plant and equipment; knowledge resources are mostly the ones obtained by integrating and transforming entrepreneurial asset resources, including techniques, information, managerial expertise, and manufacturing techniques. Political connections can bring companies a kind of scarce strategic asset, i.e., political resources [94], which we consider to be knowledge resources for two reasons. For one thing, they can have an impact on government decisions and opinions through political participation; for another, they help improve the use efficiency and transformation efficiency of entrepreneurial asset resources.

In summary, political connections are helpful to companies in obtaining all kinds of tangible and intangible resources and provide better implementation conditions and guarantees for corporate re-entrepreneurship. Accordingly, we propose our first two hypotheses:

Hypothesis 1. Political connections, including explicit political connections (a) and implicit political connections (b), have a positive impact on the acquisition of entrepreneurial asset resources.

Hypothesis 2. Political connections, including explicit political connections (a) and implicit political connections (b), have a positive impact on the acquisition of entrepreneurial knowledge resources.

\subsubsection{Entrepreneurial Resource Acquisition and Corporate Re-Entrepreneurial Performance}

Presently, the updating speed of information and technology is greater than ever before, as a result of which comes the constant changes in market competition environment. More and more companies have realized that they must be able to acquire and use resources from outside the companies continuously to establish and maintain their competitive advantages [95]. From the resource-based view, unique, and scarce resources, whether tangible or intangible, ensure companies to obtain sustainable competitiveness. Resources such as land, equipment, information, finance, tax, techniques and knowledge have a major impact on corporate performance [96]. These resources help companies not only expand external opportunities but improve their competitive and survival skills to create high profits as well [97]. In the current turbulent market environment, it is vital for corporate re-entrepreneurial performance that companies acquire abundant entrepreneurial resources by means of political connections, especially knowledge resources. Whether companies can obtain key knowledge has a greater and greater impact on corporate re-entrepreneurship. Knowledge resources play an important role in the innovation of products and manufacturing techniques [98]. They help companies gain advantages over their competitors and can also bring companies more earnings [99]. Entrepreneurial resources are necessary foundations for corporate re-entrepreneurship and acquisition of various entrepreneurial resources has a very direct impact on re-entrepreneurial performance because adequate resources are closely related to excellent performance [100]. Only if companies obtain varieties of key resources can they implement internal changes and external restructuring to achieve sustainable development [17]. Taking the above into consideration, we propose another two hypotheses:

Hypothesis 3. Entrepreneurial asset resources have a positive effect on corporate re-entrepreneurial performance.

Hypothesis 4. Entrepreneurial knowledge resources have a positive effect on corporate re-entrepreneurial performance.

Re-entrepreneurial activities need various resources for support and can be implemented in accordance with existing strategies on condition that companies have access to essential resources. In the 
process of corporate re-entrepreneurship, managers must connect and use key resources to establish and obtain competitive advantages. Political connections, as an important means of entrepreneurial resource acquisition for companies, are closely related to corporate re-entrepreneurial performance, but they can only influence it through the mediating effect of entrepreneurial resource acquisition and this mediating effect is direct and conspicuous.

Based on the above 4 hypotheses, we propose the fifth one:

Hypothesis 5. Entrepreneurial resource acquisition has a mediating effect on the relationship between political connections and corporate re-entrepreneurial performance.

\subsubsection{Political Connections and Corporate Re-Entrepreneurial Performance}

In transition economies and emerging ones, which do not always have a sound legal system, the behavior of the government is often not so normative that government intervention affects economic activities a lot [101]. Therefore, political connections have become an important means of improving corporate performance and corporate value [25]. On one hand, corporate senior executives with political status can influence government decisions by participating in the administration and discussion of government affairs, and their political status brings them more opportunities to develop favorable relationships with government officials at all levels, which can also influence government decisions to some degree [102]. These explicit political connections and implicit ones both affect corporate re-entrepreneurial behavior. On the other hand, political connections can influence corporate performance at the micro level through the arrangement of corporate financing behavior, management behavior and shareholding structure [103], which is also what companies must confront when implementing re-entrepreneurship.

From the perspective of companies, they establish channels of gaining government assistance by building close political connections with the government on account of the fact that political connections, which is an alternative mechanism to formal institutions, can bring them more entrepreneurial resources [104]. Political connections can help companies obtain advantageous regulatory environment and tax conditions [105] as well as resources such as preferential bank loans and franchise rights [106], all of which guarantee that companies acquire sustainable competitiveness and thereby contribute to the long-term improvement of corporate value [107]. An increasing number of companies have realized that establishing political connections with the government actively, which has great and efficient effects on government policies, the formulation of laws, and regulations and companies' acquiring entrepreneurial resources, is vital for them to gain competitive advantages [108] and achieve better corporate re-entrepreneurial performance.

China's economy has seen a rapid development of about 30 years. Many companies, especially those in the real estate industry, are now faced with development bottlenecks and the internal and external environment they lie in are quite different from those at their start-up stage, which seriously restricts their further development. The number of real estate companies in China is quite considerable, with 1656 out of 3582 Chinese A-share listed companies possessing real estate assets by the end of 2018. However, with the continuous constraints of government regulatory policies, China has seen essential changes in the real estate industry where most of the real estate companies need to improve their corporate performance through entrepreneurship. As a result, it has become a "new normal" for real estate companies to implement re-entrepreneurship [109]. There has been a new trend of re-entrepreneurship among real estate companies towards finance, the Internet, smart communities, high-efficiency agriculture and culture-oriented tourism [110]. However, real estate companies cannot acquire these re-entrepreneurial opportunities without government guidance and support on account of the fact that part or all the resources, policies, and regulatory authority over certain industries needed for re-entrepreneurship are in the control of the government. An efficient way for real estate companies, private ones in particular, to obtain these resources and policies as well as breaking through industry barriers is to establish political connections. Under China's specific institutional system, political 
connections, which help real estate companies establish favorable relationships with the government, have certain economic functions and thereby play a significant role in improving re-entrepreneurial performance of real estate companies.

In conclusion, political connections contribute to companies' acquiring competitive advantages and improving re-entrepreneurial performance, which leads to our sixth hypothesis:

Hypothesis 6. Political connections, including explicit political connections (a) and implicit political connections (b), have positive impacts on corporate re-entrepreneurial performance.

\subsubsection{Institutional Environment and Corporate Re-Entrepreneurial Performance}

According to the institutional theory, the external environment where a company lies is a system, a system of institutional environment, to which corporate re-entrepreneurial activities are indispensable. In today's world of globalization, the differentiation of institutional environment is more noticeable, especially in transition economies and developing countries. Under such circumstances, companies must have resource acquisition capabilities matching institutional environment, strategic adjustment abilities keeping up with the changes of institutional environment and abilities coping with the changes if they want to maintain their competitive advantages.

The relationship between political connections and corporate re-entrepreneurial performance is affected inevitably by institutional environment [111]. The changes in institutional environment can alter the communication between companies and the government, which makes it difficult to predict the impacts political connections have on corporate performance. In developed countries with a sound legal system, the development of companies is restricted by market rules, in which case political connections do not demonstrate substantial advantages and therefore will not increase corporate economic benefits in a direct way. However, in transition economies and developing countries such as China and Brazil, where the government holds the dominant position in economic regulation and is in control of large quantities of resources, the political system is not sound enough to regulate the economic development in most aspects, especially the relationship among companies, the government and regulatory authorities. As a result, companies are sure to actively seek for political connections to increase their re-entrepreneurial opportunities and promote their re-entrepreneurship performance. Political connections make it easier for companies to overcome the disadvantage of the high cost of market contract transactions and thus form the "resource-saving" effect, especially under the circumstances of constant changes in institutional environment, which is beneficial to the innovation of companies as well [112]. The more dynamic changes institutional environment undergoes, the stronger desire companies must seek resources through political connections; the more settled institutional environment, the less possible it is for companies to acquire resources through political connections. Therefore, the moderating effect of institutional environment on the relationship between political connections and corporate re-entrepreneurial performance should be given full consideration if companies are to conduct corporate re-entrepreneurship. Following this argument, we propose our seventh hypothesis:

Hypothesis 7. Institutional environment has a moderating effect on the relationship between political connections, including explicit political connections (a) and implicit political connections (b), and corporate re-entrepreneurial performance.

\section{Research Design}

\subsection{Basic Model Construction}

Political connections, as an important supplement to the market mechanism in transition economies, have either direct or indirect impacts on companies' acquiring external resources and hence influence corporate re-entrepreneurial performance. It has become a significant part of overall corporate 
strategy of companies to establish and apply political connections [113]. Additionally, the institutional environment where a company lies has a moderating effect on the relationship between political connections and corporate re-entrepreneurship and can regulate the impacts of political connections on corporate re-entrepreneurship. Following this argument, we construct a research framework with entrepreneurial resource acquisition as the mediating variable and institutional environment as the moderating variable in order to analyze the influence mechanism of political connections on corporate re-entrepreneurial performance by means of entrepreneurial resource acquisition, which is shown in the following figure (Figure 1).

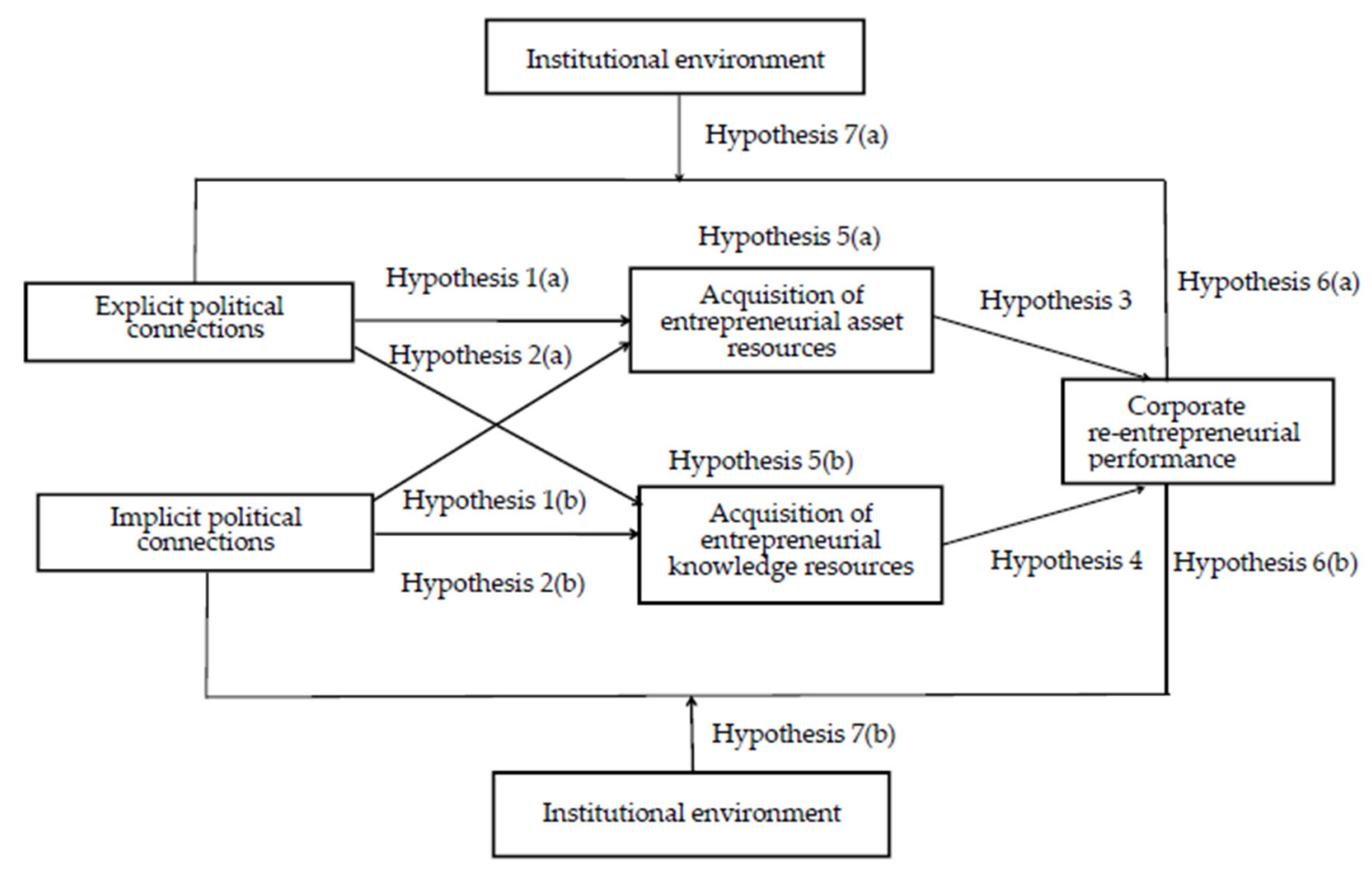

Figure 1. Theoretical research framework.

\subsection{Choice of Samples and Collection of Data}

The real estate industry, which is a representative industry in China's economic development, has witnessed the growing process of China's economy in the past 40 years or so. China's real estate industry had been developing at a high speed since the 1990s, which made it one of the pillar industries of the country in a very short time, until the global economic recession in 2008. Since then, the real estate industry has been in the predicament of sluggish development, and the business of real estate companies has suffered serious setbacks, especially in recent years. Cutting excess urban real estate inventory has become one of the major tasks for the development of China's real estate industry. Under such circumstances, the traditional development patterns of the real estate industry are difficult to sustain, which has caused many real estate companies to embark on re-entrepreneurship and successful cases continue to emerge. In addition, re-entrepreneurship of real estate companies involves many business fields, such as agriculture, the Internet and artificial intelligence which makes the entrepreneurial activities of real estate companies present some universal features. On the other hand, the development of real estate companies in China is inseparable from key resource factors such as land, funds, policies, and administrative examination and approval. Almost all these resources are in the control of the government, which means that real estate companies must establish close connections with the government to acquire the resources. Therefore, compared with companies in other industries, the real estate companies are more politically connected, which makes it easier for them to exert the impacts of political connections during the process of their re-entrepreneurship. As a 
result, it completely meets the demands of the research subject to use real estate companies as the sample in the study.

The questionnaire contains information concerning political connections and company management and such information is only available to corporate senior executives and core management staff. In addition, as the choice of samples is limited by regions, availability, time, and money, we set the following criteria when choosing the samples: 1 . The sample companies must be in the field of real estate development, construction, design, and consultancy or some other related ones. 2 . The sample companies should have a history of more than five years. 3. The respondents should be part of the core management team of the sample companies, i.e., managers of functional departments and above.

The survey questionnaires include paper ones and electronic ones. We did the survey from March to July in 2018 and distributed the questionnaires with the assistance of the construction committee in some large and medium-sized cities such Dalian, Harbin, Shenyang, Changchun, and Jilin. Totally, 355 out of 450 questionnaires were recovered, among which 223 were valid. From positions of the interviewees, size of the investigated companies and time of their establishment, we can see that the samples spread evenly and are quite representative.

\subsection{Measurement of Variables}

\subsubsection{Independent Variable: Political Connections}

A review of previous studies has found that definitions of political connections are mostly focused on whether corporate senior executives hold or used to hold certain administrative positions while political connections established on the basis of personal relationships between corporate senior executives and their teachers, friends or family members are often overlooked. Accordingly, the study adopts the categories and measurement methods of political connections put forward by Wang [82] and Zhang et al. [114] and divides political connections into explicit ones and implicit ones. Explicit political connections refer to the external connections between companies and the government established in the way that corporate senior executives have certain political status or the government possesses a certain number of company shares: 1 . If senior executives of a company hold or used to hold positions in government departments or they are or used to be deputies to China's People's Congress or CPPCC members, then the company is considered to be politically connected in an explicit way; 2. If the government or a state-owned enterprise possesses a certain number of company shares, which means the interests of the company and the government or the state-owned enterprise are consistent to some degree, then the company is considered to have explicit political connections. Implicit political connections are flexible connections between a company and the government based on personal relationships: 1. If senior executives of a company are family members, friends, relatives, former classmates or fellow-townsmen of government officials (including incumbent or former government officials, deputies to China's People's Congress and CPPCC members), the company is considered to have implicit political connections; 2 . If a company employs influential political figures (including former government officials, deputies to China's People's Congress and CPPCC members) as part-time consultants, the company is considered to have implicit political connections.

Meanwhile, taking China's actual conditions into consideration, the study adopts Wu's method of assigning a value to political connections in accordance with administrative ranks that corporate senior executives used to hold when working in government departments [115]. If corporate senior executives hold or used to hold administrative positions, or they are or used to be deputies to China's People's Congress or CPPCC members, their political connections are marked from 5 to 1 , which respectively stands for above provincial or ministerial level, provincial or ministerial level, prefecture level, county level, and town level. If they have no political connections, then the value is 0 . 


\subsubsection{Mediating Variable: Entrepreneurial Resource Acquisition}

According to Zhu et el., entrepreneurial resource acquisition can be divided into entrepreneurial asset resource acquisition and entrepreneurial knowledge resource acquisition. We used Pfeffer and Salancick's measurement method to measure resource acquisition in three items, "can obtain resources in large quantities", "can obtain resources through many channels" and "can obtain resources at a low cost" [116], by Likert Scale with 1 representing "totally disagree" and 5 referring to "totally agree".

\subsubsection{Moderating Variable: Institutional Environment}

In China, among the many methods of using objective data as a proxy variable to interpret institutional environment, the most widely used one is to adopt the marketization process index from Marketization Index of China's provinces: Neri Report 2018 by Fan and Wang as the proxy variable of institutional environment. The index, which is adopted in the study, is issued every two or three years and is used to explain the impacts of differences in marketization degree in different districts. This indicator system mainly consists of five indexes, namely the relationship between the government and the market, the development of non-state-owned economy, the development degree of the product market, the development degree of the factor market, and the development of market intermediary organizations and the environment of legal institutions. Based on the opinion of Yan et al., the study divides these indexes into four grades according to the score and assigns a value to each grade from 1 to 4 . The higher the value, the greater the degree of marketization, and the better institutional environment.

\subsubsection{Dependent Variable: Corporate Re-Entrepreneurial Performance}

Using the ideas of Du et al. as a reference, the study adopts the scale of corporate entrepreneurial performance put forward by Murphy [117]. This scale examines corporate re-entrepreneurial performance by applying comprehensive indexes, i.e., financial and non-financial ones and has attracted broad attention of later scholars. It mainly involves profitability, market growth, and employee satisfaction, consisting of seven indexes, which are rate of return on assets, market share growth rate, profit before tax, sales revenue, employee satisfaction, employee turnover, and customer satisfaction and loyalty. However, financial indexes are corporate trade secrets and are hard to obtain, so the study adopts the subjective assessment method to measure corporate re-entrepreneurial performance [44] by Likert Scale with 1 representing "totally disagree" and 5 referring to "totally agree". The relevant variables are shown as follows (Table 1).

\subsection{Reliability and Validity of Samples}

\subsubsection{Analysis of Reliability}

Reliability shows whether the results of the measurement scale are stable [118]. It means high reliability if a scale can eliminate errors. Reliability is usually classified into three categories, parallel-forms reliability, test-retest reliability, and internal consistency reliability. The last one was adopted in the study to evaluate the reliability of the scale. It is usually believed that the samples are of high reliability if the coefficient of Cronbach's Alpha $(\alpha)$ exceeds 0.7 [119] (Table 2). 
Table 1. Elaboration of Variables Concerned.

\begin{tabular}{|c|c|c|}
\hline Types & Names & Elaboration \\
\hline \multirow{4}{*}{$\begin{array}{l}\text { Independent } \\
\text { Variable: } \\
\text { Political connections }\end{array}$} & a1: active explicit political connections & $\begin{array}{l}\text { Explicit political connections } \\
\text { established actively }\end{array}$ \\
\hline & a2: passive explicit political connections & $\begin{array}{c}\text { Explicit political connections } \\
\text { established before or in a passive way }\end{array}$ \\
\hline & a3: active implicit political connections & $\begin{array}{l}\text { Implicit political connections } \\
\text { established actively }\end{array}$ \\
\hline & a4: passive implicit political connections & $\begin{array}{c}\text { Implicit political connections } \\
\text { established before or in a passive way }\end{array}$ \\
\hline \multirow{6}{*}{$\begin{array}{c}\text { Mediating variable: } \\
\text { Acquisition of entrepreneurial } \\
\text { resources }\end{array}$} & $\begin{array}{c}\text { a5: Quantity of knowledge resources } \\
\text { acquired }\end{array}$ & $\begin{array}{l}\text { Acquire entrepreneurial knowledge } \\
\text { resources in large quantities }\end{array}$ \\
\hline & $\begin{array}{l}\text { a6: Channels of acquiring knowledge } \\
\text { resources }\end{array}$ & $\begin{array}{l}\text { Acquire entrepreneurial knowledge } \\
\text { resources through many channels }\end{array}$ \\
\hline & a7: Cost of acquiring knowledge resources & $\begin{array}{l}\text { Acquire entrepreneurial knowledge } \\
\text { resources at a low cost }\end{array}$ \\
\hline & a8: Quantity of asset resources acquired & $\begin{array}{l}\text { Acquire entrepreneurial asset } \\
\text { resources in large quantities }\end{array}$ \\
\hline & a9: Channels of acquiring asset resources & $\begin{array}{l}\text { Acquire entrepreneurial asset } \\
\text { resources through many channels }\end{array}$ \\
\hline & a10: Cost of acquiring asset resources & $\begin{array}{l}\text { Acquire entrepreneurial asset } \\
\text { resources at a low cost }\end{array}$ \\
\hline \multirow{5}{*}{$\begin{array}{l}\text { Moderating variable: } \\
\text { Institutional environment }\end{array}$} & $\begin{array}{l}\text { a11: The relationship between the } \\
\text { government and market }\end{array}$ & $\begin{array}{l}\text { The higher the value, the less the } \\
\text { government intervenes the market }\end{array}$ \\
\hline & $\begin{array}{l}\text { a12: The development of non-state-owned } \\
\text { economy }\end{array}$ & $\begin{array}{l}\text { The higher the value, the greater the } \\
\text { degree of marketization }\end{array}$ \\
\hline & $\begin{array}{l}\text { a13: The development degree of the } \\
\text { product market }\end{array}$ & $\begin{array}{l}\text { The higher the value, the higher the } \\
\text { development level of product market }\end{array}$ \\
\hline & $\begin{array}{l}\text { a14: The development degree of the factor } \\
\text { market }\end{array}$ & $\begin{array}{l}\text { The higher the value, the more } \\
\text { developed the factor market }\end{array}$ \\
\hline & $\begin{array}{l}\text { a15: The development of market } \\
\text { intermediary organizations and the } \\
\text { environment of legal institutions }\end{array}$ & $\begin{array}{l}\text { The higher the value, the higher the } \\
\text { level of legal system, and the better } \\
\text { property rights are protected }\end{array}$ \\
\hline \multirow{7}{*}{$\begin{array}{l}\text { Dependent variable: } \\
\text { Re-entrepreneurial } \\
\text { performance }\end{array}$} & a16: rate of return on assets & Net profit/ Balance of total assets \\
\hline & a17: market share growth rate & $\begin{array}{l}\text { The market sales of a certain } \\
\text { calculation period: The market sales } \\
\text { of the period before/The market sales } \\
\text { of the period before }\end{array}$ \\
\hline & a18: profit before tax & $\begin{array}{l}\text { Total profit, i.e., the profit before } \\
\text { paying the income tax }\end{array}$ \\
\hline & a19: sales revenue & $\begin{array}{l}\text { The natural logarithm of the main } \\
\text { business revenue }\end{array}$ \\
\hline & a20: employee satisfaction & Actual feelings/ Expectation value \\
\hline & a21: employee turnover & $\begin{array}{l}\text { The number of employees leaving } \\
\text { office/(The number of employees } \\
\text { leaving office }+ \text { The number of } \\
\text { employees in office at the end of a } \\
\text { calculation period) } \times 100 \%\end{array}$ \\
\hline & a22: customer satisfaction and loyalty & $\begin{array}{l}\text { The number of satisfied customers/ } \\
\text { The total number of customers } \times 100 \%\end{array}$ \\
\hline
\end{tabular}

Note: Corporate senior executives cover chairmen of the board, general managers, deputy general managers, and chief financial officers. 
Table 2. Results of Reliability Analysis.

\begin{tabular}{ccc}
\hline Measurement Dimensions & Items & Cronbach's $\alpha$ \\
\hline Explicit political connections & 2 & 0.874 \\
Implicit political connections & 2 & 0.961 \\
Acquisition of entrepreneurial knowledge resources & 3 & 0.954 \\
Acquisition of entrepreneurial Asset resources & 3 & 0.979 \\
Corporate re-entrepreneurial performance & 7 & 0.984 \\
Total & 17 & 0.976 \\
\hline
\end{tabular}

The analysis of the data in the above table suggests that the coefficients of the latent variables except explicit political connections are all greater than 0.9 and that the data from each dimension is consistent, which means that the survey is reliable. The reliability coefficient of the overall questionnaire is 0.976 , which indicates that the questionnaire data has good reliability and can meet the needs of the study.

\subsubsection{Analysis of Validity}

Validity is about to what degree a scale shows what the researchers want to measure [80]. Construct validity is the key criterion to be tested in this paper. Both the content and the construct validity of the scale are measured by applying the confirmatory factor analysis (CFA) in Mplus 7.0 software, before which the principal component analysis of the factor analysis needs to be used to test the sample data.

\section{Principal Component Analysis}

Factor analysis is done based on the premise that there is correlation among variables and the correlation should be high enough for factor analysis. The Kaiser-Meyer-Olkin Measure of Sampling Adequacy (KMO) and Bartlett's Test of Sphericity are used to evaluate the correlation. The closer the KMO coefficient is to 1, the more appropriate it is for factor analysis. Generally, the KMO coefficient is required to be above 0.7. Bartlett's Test of Sphericity is used to examine whether the correlation matrix is significantly different from zero. A prominent test of sphericity indicates that the correlation coefficient meets the requirements. The results we get by using SPSS 22.0 software are that KMO is 0.921 and the chi-square value of Bartlett's Test of Sphericity is 7317.645 (degree of freedom is 136), $p=0.000$, indicating that the sample data is very suitable for principal component analysis.

The results of principal component analysis of the sample data are shown in Table 3 below, from which it can be seen that by using the method of variance maximization to rotate and extract five principal components, the cumulative contribution rate reaches $92.715 \%$.

Table A1 in the Appendix A shows that the five components extracted are entirely consistent with the original structure of the questionnaire, which preliminarily indicates that its inner structure is reasonable. 
Table 3. Results of Principal Component Analysis.

\begin{tabular}{|c|c|c|c|c|c|c|c|c|c|}
\hline \multirow{2}{*}{ Component } & \multicolumn{3}{|c|}{ Initial Eigenvalue } & \multicolumn{3}{|c|}{$\begin{array}{c}\text { Extraction Sums of Squared } \\
\text { Loadings }\end{array}$} & \multicolumn{3}{|c|}{ Rotation Sums of Squared Loadings } \\
\hline & Total & $\begin{array}{l}\text { Percentage } \\
\text { of Variance }\end{array}$ & $\begin{array}{l}\text { Cumulative } \\
\text { Percentage }\end{array}$ & Total & $\begin{array}{l}\text { Percentage } \\
\text { of Variance }\end{array}$ & $\begin{array}{l}\text { Cumulative } \\
\text { Percentage }\end{array}$ & Total & $\begin{array}{l}\text { Percentage } \\
\text { of Variance }\end{array}$ & $\begin{array}{l}\text { Cumulative } \\
\text { Percentage }\end{array}$ \\
\hline 1 & 12.527 & 73.687 & 73.687 & 12.527 & 73.687 & 73.687 & 6.184 & 36.376 & 36.376 \\
\hline 2 & 1.275 & 7.500 & 81.187 & 1.275 & 7.500 & 81.187 & 2.940 & 17.293 & 53.669 \\
\hline 3 & 0.793 & 4.667 & 85.854 & 0.793 & 4.667 & 85.854 & 2.345 & 13.797 & 67.466 \\
\hline 6 & 0.360 & 2.115 & 94.831 & & & & & & \\
\hline 7 & 0.242 & 1.421 & 96.252 & & & & & & \\
\hline 8 & 0.177 & 1.040 & 97.292 & & & & & & \\
\hline 9 & 0.132 & 0.779 & 98.071 & & & & & & \\
\hline 10 & 0.109 & 0.639 & 98.710 & & & & & & \\
\hline 11 & 0.069 & 0.408 & 99.118 & & & & & & \\
\hline 16 & 0.009 & 0.052 & 99.977 & & & & & & \\
\hline 17 & 0.004 & 0.023 & 100.000 & & & & & & \\
\hline
\end{tabular}

\section{CFA}

In this study, CFA is not only used to verify the rationality of the construct validity and theoretical logic of the questionnaire but is also a preliminary step towards the subsequent structural equation analysis. Its results provide important references for the modification of structural models.

Mplus 7.0 software is used in the study to construct models and then do the calculation. After modifying the collinearity, we get the values of model fit indices. As is shown in the table below, the ratio of chi-square to degrees of freedom is 2.889, which is good. The Comparative Fit Index (CFI) and the Tucker-Lewis Index (TLI) are also good and so are the root mean square error of approximation (REMSA) and standardized root mean square residual (SRMR), which are less than 0.1 and 0.08 , respectively. Overall, the model fit is relatively good, suggesting that the questionnaire of the study has good construct validity (Table 4 ).

Table 4. Fit indices of CFA.

\begin{tabular}{cccc}
\hline \multirow{2}{*}{ Indices } & \multicolumn{2}{c}{ Evaluation Criteria } & \multirow{2}{*}{ Fit Values } \\
\cline { 2 - 3 } & Acceptable & Good & \\
\hline Chi-square/df & $(3.0,5.0)$ & $<3.0$ & 2.889 \\
CFI & $(0.7,0.9)$ & $>0.9$ & 0.973 \\
TLI & $(0.7,0.9)$ & $>0.9$ & 0.965 \\
RMESA & $(0.08,0.1)$ & $<0.08$ & 0.092 \\
SRMR & $<0.1$ & $<0.08$ & 0.043 \\
\hline
\end{tabular}

The estimated results in Table A2 of Appendix A, all of which are greater than 0.84 , show that there is a high correlation between each of the first level indicators chosen and the path coefficients of CFA, indicating that the choice of indexes and CFA are highly correlative. The values of SE are all low, reflecting a small sampling error and high precision of calculation results. The values of est/se are all high and $p$-value is very low, suggesting that the results of measurement have statistical differences and are valid to be adopted.

\section{Empirical Results and Analyses}

\subsection{Descriptive Statistical Analysis}

Before the structural equation modelling, descriptive statistics of each variable involved were carried out to study the statistical characteristics of each variable and preliminarily judge the correlation 
between the variables. The results are shown below in Table 5. As far as the ownership of the sample companies is concerned, all kinds of companies are encompassed with private ones in the majority. As far as the scale of the sample companies is concerned, companies of different scales are involved, among which the proportion of the ones with 100 to 500 employees is a little larger, indicating that the sample companies are mainly small and medium-sized ones. As for the industry concerned, real estate development and other related ones are all involved, with the industry of real estate development in a slight majority. In terms of the capital, companies with a registered capital of $¥ 5$ million to $¥ 1000$ million are all covered, of which the ones with a registered capital of $¥ 300$ million to $¥ 1000$ million are in the majority and the ones with a registered capital of $¥ 5$ million or less are the least involved. These data indicate that the sample companies chosen can represent the whole real estate industry, which means that the conclusions drawn from the empirical analysis based on these data are of universal significance statistically.

Table 5. The statistical characteristics of the sample companies.

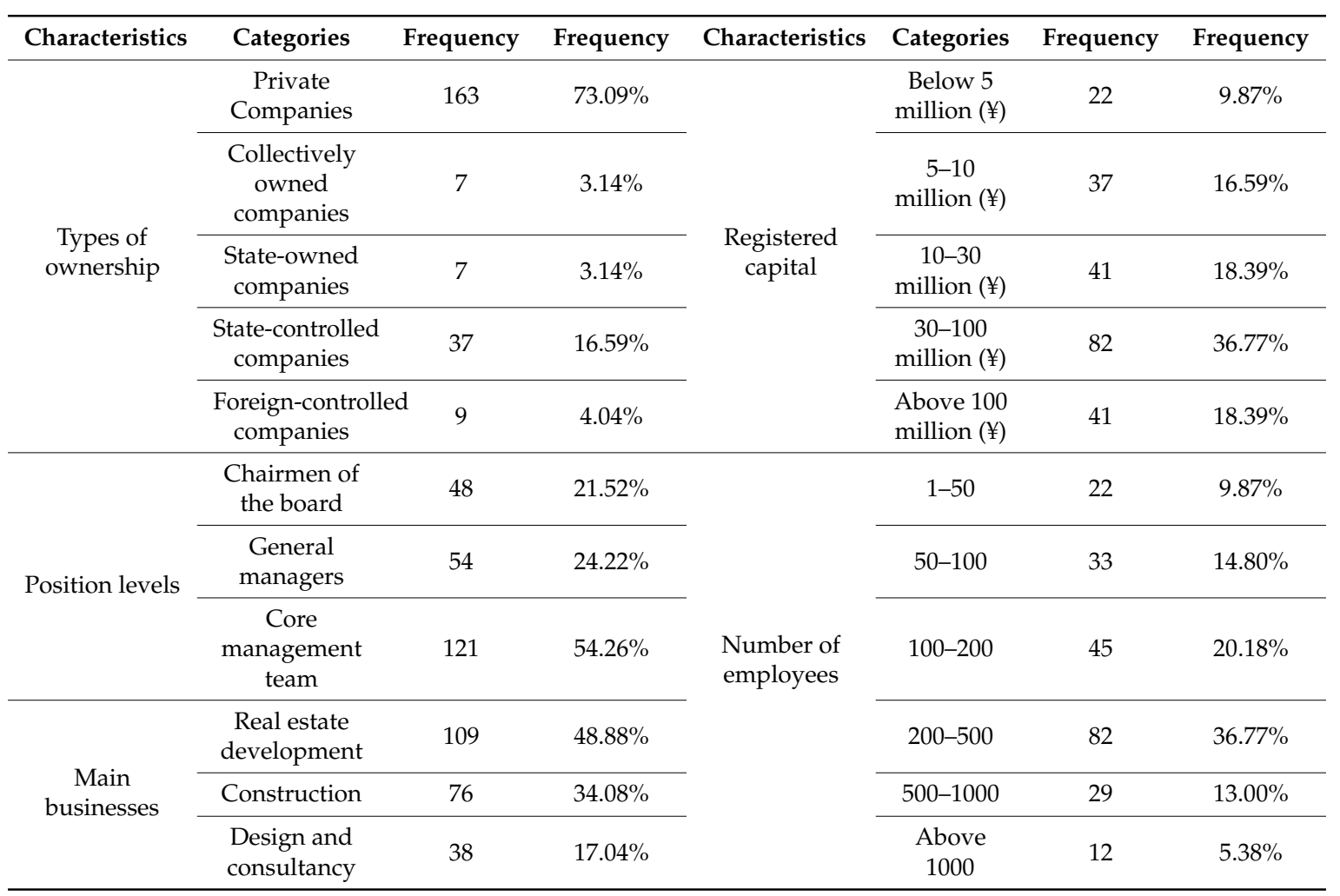

\subsection{Analysis of Main Effects}

This study adopts the method of structural equation analysis to test the models, which can handle multiple dependent variables and allow measurement errors of independent variables and dependent variables. Besides, the method can also estimate both the factor structure and the relationship between factors in the same model. It allows more flexible settings of measurement models and can estimate the fitting degree of the whole model.

This study uses Mplus 7.0 software to construct full structural equation models, calculate the path between the latent variables and ascertain the relationship between the latent variables.

Through structural equation analysis, it can be seen that the ratio of chi-square to the degree of freedom is 3.27, which is within the range between 3.0 and 5.0, meaning that the hypothetical model is acceptable. The results also demonstrate that the hypothetical model fits the observed data $(\mathrm{CFI}=0.967$, TLI $=0.958$, SRMR $=0.055)$ except that RMESA $(=0.101)$ is very close to the maximum acceptable value. On the whole, the degree of fit of the latent variables in the study is good, suggesting 
that the data obtained from the survey can reflect the correlations between the latent variables and that the analysis of the research subject based on the data is reliable (Table 6).

Table 6. Fit indices.

\begin{tabular}{cccc}
\hline \multirow{2}{*}{ Indices } & \multicolumn{2}{c}{ Evaluation Criteria } & \multirow{2}{*}{ Fit Values } \\
\cline { 2 - 3 } & Acceptable & Good & \\
\hline Chi-square/df & $(3.0,5.0)$ & $<3.0$ & 3.27 \\
CFI & $(0.7,0.9)$ & $>0.9$ & 0.967 \\
TLI & $(0.7,0.9)$ & $>0.9$ & 0.958 \\
RMESA & $(0.08,0.1)$ & $<0.08$ & 0.101 \\
SRMR & $<0.1$ & $<0.08$ & 0.055 \\
\hline
\end{tabular}

From the analysis results of the relationship between latent variables (Table 7), it can be seen that explicit political connections display obvious positive regression relation to entrepreneurial asset resources $(\mathrm{B}=0.615, p=0.000)$, which means that explicit political connections help increase entrepreneurial asset resources, providing support for Hypothesis 1(a). In addition, so do implicit political connections ( $\mathrm{B}=0.290, p=0.000$ ), supporting Hypothesis $1(\mathrm{~b})$. Similarly, explicit political connections display obvious positive regression relation to entrepreneurial knowledge resources $(\mathrm{B}=0.514, p=0.000)$, which means that explicit political connections can help increase entrepreneurial knowledge resources, providing support for Hypothesis 2(a). Implicit political connections also bear noticeable positive regression relation to entrepreneurial knowledge resources $(B=0.438, p=0.000$ ), which means implicit political connections can help increase entrepreneurial knowledge resources, providing support for Hypothesis 2(b). Table 7 suggests that explicit political connections to corporate re-entrepreneurial performance $(B=0.206, p=0.026)$, implicit political connections to corporate re-entrepreneurial performance $(B=0.307, p=0.002)$, entrepreneurial knowledge resources to corporate re-entrepreneurial performance $(B=0.218, p=0.029)$, and entrepreneurial asset resources to corporate re-entrepreneurial performance $(B=0.143, p=0.050)$ all bear noticeable positive regression relation, indicating that both explicit and implicit political connections have positive promoting effects on corporate re-entrepreneurial performance and that entrepreneurial knowledge resources as well as entrepreneurial asset ones have positive impacts on corporate re-entrepreneurial performance. Therefore, Hypothesis 6(a), Hypothesis 6(b), Hypothesis 3, and Hypothesis 4 are all supported.

Table 7. Path coefficients of main effects.

\begin{tabular}{lcccc}
\hline & Estimate & S.E. & Est./S.E. & $p$-Value \\
\hline Entrepreneurial asset resources $\leftarrow$ Explicit political connections & 0.615 & 0.070 & 8.751 & 0.000 \\
\hline Entrepreneurial asset resources $\leftarrow$ Implicit political connections & 0.290 & 0.071 & 4.054 & 0.000 \\
\hline $\begin{array}{l}\text { Entrepreneurial knowledge resources } \leftarrow \text { Explicit political } \\
\text { connections }\end{array}$ & 0.514 & 0.062 & 8.268 & 0.000 \\
\hline $\begin{array}{l}\text { Entrepreneurial knowledge resources } \leftarrow \text { Implicit political } \\
\text { connections }\end{array}$ & 0.438 & 0.061 & 7.212 & 0.000 \\
\hline $\begin{array}{l}\text { Corporate re-entrepreneurial performance } \leftarrow \text { Explicit political } \\
\text { connections }\end{array}$ & 0.206 & 0.093 & 2.223 & 0.026 \\
\hline $\begin{array}{l}\text { Corporate re-entrepreneurial performance } \leftarrow \text { Implicit political } \\
\text { connections }\end{array}$ & 0.307 & 0.099 & 3.111 & 0.002 \\
\hline $\begin{array}{l}\text { Corporate re-entrepreneurial performance } \leftarrow \text { Entrepreneurial } \\
\text { knowledge resources }\end{array}$ & 0.218 & 0.100 & 2.178 & 0.029 \\
\hline $\begin{array}{l}\text { Corporate re-entrepreneurial performance } \leftarrow \text { Entrepreneurial asset } \\
\text { resources }\end{array}$ & 0.143 & 0.073 & 1.957 & 0.050 \\
\hline
\end{tabular}




\subsection{The Mediating Effect of Entrepreneurial Resource Acquisition}

As is shown in Table 8 below, the mediating effect of explicit political connections on corporate re-entrepreneurial performance, which is $0.285(p=0.000)$, is of statistical significance. The mediating effect comes from entrepreneurial knowledge resources, whose mediating effect value is 0.127 , and entrepreneurial asset resources, whose mediating effect value is 0.158 . Both are statistically of significance after statistical tests, with $p$-value both less than 0.05 . In addition, as a result of the fact that the direct effect of explicit political connections on corporate re-entrepreneurial performance is of statistical significance, it is partial mediating effect.

Table 8. Path coefficients of the mediating effect.

\begin{tabular}{|c|c|c|c|c|}
\hline & Estimate & S.E. & Est./S.E. & $p$-Value \\
\hline \multicolumn{5}{|l|}{$\begin{array}{l}\text { Corporate re-entrepreneurial performance } \leftarrow \text { Explicit political } \\
\text { connections }\end{array}$} \\
\hline Sum of indirect & 0.285 & 0.068 & 4.196 & 0.000 \\
\hline \multicolumn{5}{|l|}{ Specific indirect } \\
\hline $\begin{array}{l}\text { Corporate re-entrepreneurial performance-Acquisition of } \\
\text { entrepreneurial knowledge resources-Explicit political connections }\end{array}$ & 0.127 & 0.057 & 2.205 & 0.027 \\
\hline $\begin{array}{l}\text { Corporate re-entrepreneurial performance-Acquisition of } \\
\text { entrepreneurial asset resources-Explicit political connections }\end{array}$ & 0.158 & 0.052 & 3.013 & 0.003 \\
\hline \multicolumn{5}{|l|}{$\begin{array}{l}\text { Corporate re-entrepreneurial performance } \leftarrow \text { Implicit political } \\
\text { connections }\end{array}$} \\
\hline Sum of indirect & 0.194 & 0.056 & 3.469 & 0.001 \\
\hline \multicolumn{5}{|l|}{ Specific indirect } \\
\hline $\begin{array}{l}\text { Corporate re-entrepreneurial performance-Acquisition of } \\
\text { entrepreneurial knowledge resources-Implicit political } \\
\text { connections }\end{array}$ & 0.060 & 0.032 & 1.888 & 0.059 \\
\hline $\begin{array}{l}\text { Corporate re-entrepreneurial performance-Acquisition of } \\
\text { entrepreneurial asset resources-Implicit political connections }\end{array}$ & 0.135 & 0.049 & 2.772 & 0.006 \\
\hline
\end{tabular}

The total of the mediating effect value of implicit political connections on corporate re-entrepreneurial performance is $0.194(p=0.001)$, indicating that this mediating effect is of statistical significance. It also comes from entrepreneurial knowledge resources and entrepreneurial asset resources, with the mediating effect value being 0.060 and 0.135 , respectively. The $p$-value of the mediating effect of entrepreneurial knowledge resources is 0.059 , which is close to 0.05 , meaning that it may be of statistical significance, while that of entrepreneurial asset resources is 0.006 , indicating that it has remarkable statistical significance. Meanwhile, as the direct effect of implicit political connections on corporate re-entrepreneurial performance is of statistical significance, it is also partial mediating effect.

Based on the above analysis, we find support for the positive mediating effect of both acquisition of entrepreneurial knowledge resources and entrepreneurial asset ones on the relationship between political connections and corporate re-entrepreneurial performance, leading to the verification of Hypothesis 5(a) and Hypothesis 5(b).

\subsection{The Moderating Effect of Institutional Environment}

Using Institutional Environment as the moderating variable, explicit political connections and implicit ones as the independent variables, and corporate re-entrepreneurial performance as the dependent variable, the study carried out data analysis by the mean value of each dimension.

Through the general linear model, it can be found that the interaction items between explicit political connections and institutional environment have remarkable statistical significance for corporate 
re-entrepreneurial performance $(\mathrm{F}=2.159, p=0.002)$, and so it is with implicit political connections $(\mathrm{F}=2.228, p=0.001)$. It means that institutional environment plays a positive moderating role in the impacts of both explicit and implicit political connections on corporate re-entrepreneurial performance (Tables 9 and 10).

Table 9. Test of the moderating role of institutional environment in the relationship between explicit political connections and corporate re-entrepreneurial performance.

\begin{tabular}{cccccc}
\hline Sources & $\begin{array}{c}\text { Sum of Squares of } \\
\text { Category III }\end{array}$ & $\begin{array}{c}\text { Degree of } \\
\text { Freedom }\end{array}$ & $\begin{array}{c}\text { Mean } \\
\text { Square }\end{array}$ & F & Significance \\
\hline Modified model & $135.394^{\mathrm{a}}$ & 52 & 2.604 & 8.138 & 0.000 \\
Intercept & 519.113 & 1 & 519.113 & 1622.460 & 0.000 \\
Explicit political connections & 21.555 & 8 & 2.694 & 8.421 & 0.000 \\
Institutional Environment & 23.285 & 17 & 1.370 & 4.281 & 0.000 \\
Interaction & 18.650 & 27 & 0.691 & 2.159 & 0.002 \\
Error & 54.392 & 170 & 0.320 & & \\
Total & 3306.735 & 223 & & & \\
Total after modification & 189.786 & 222 & & &
\end{tabular}

${ }^{\mathrm{a}} \mathrm{R}$-square $=0.713$ (R-square $=0.626$ after adjustment).

Table 10. Test of the moderating role of institutional environment in the relationship between implicit political connections and corporate re-entrepreneurial performance.

\begin{tabular}{cccccc}
\hline Sources & $\begin{array}{c}\text { Sum of Squares of } \\
\text { Category III }\end{array}$ & $\begin{array}{c}\text { Degree of } \\
\text { Freedom }\end{array}$ & $\begin{array}{c}\text { Mean } \\
\text { Square }\end{array}$ & F & Significance \\
\hline Modified model & $137.551^{\text {a }}$ & 56 & 2.456 & 7.806 & 0.000 \\
Intercept & 751.735 & 1 & 751.735 & 2388.974 & 0.000 \\
Implicit political connections & 15.481 & 7 & 2.212 & 7.028 & 0.000 \\
Institutional environment & 21.701 & 17 & 1.277 & 4.057 & 0.000 \\
Interaction & 22.434 & 32 & 0.701 & 2.228 & 0.001 \\
Error & 52.235 & 166 & 0.315 & & \\
Total & 3306.735 & 223 & & & \\
Total after modification & 189.786 & 222 & &
\end{tabular}

In conclusion, the moderating effect of institutional environment on the relationship between political connections and corporate re-entrepreneurial performance, i.e., Hypothesis 7(a) and Hypothesis $7(b)$, is verified.

\section{Conclusions and Management Implications}

\subsection{Conclusions}

Under the circumstances of global competition, how to sustain long-term competitiveness has become a great challenge for economic organizations and therefore conducting corporate re-entrepreneurship has become necessary for most of them. In such context, this paper builds a research framework of political connections, entrepreneurial resource acquisition, institutional environment and corporate re-entrepreneurial performance and focuses on the influence mechanism of political connections on corporate re-entrepreneurial performance by conducting a survey of core figures such as directors, general managers, and other senior executives in China's 223 real estate companies. It also explores the mediating role of entrepreneurial resource acquisition and the moderating role of institutional environment in the influence process. Through the regression testing, all the hypotheses are supported, and the study arrives at the following conclusions.

Firstly, favorable political connections help promote corporate re-entrepreneurial performance, which is well in line with the research result of Liu et al. that political connections are an important means of promoting corporate performance [68] and also verifies Baron's view that the motivation of corporate 
political activities is to acquire resources and competitive advantages [120]. This conclusion also verifies indirectly the resource-based view, i.e., political connections, as a kind of key resources, are an informal alternative to market mechanism [121]. Another significant finding is that entrepreneurial resource acquisition plays a positive mediating role in the relationship between political connections and corporate re-entrepreneurial performance. Strengthening political connections contributes to the acquisition of entrepreneurial knowledge resources and entrepreneurial asset ones, and the acquisition of these resources helps companies identify and choose re-entrepreneurial opportunities, gain competitive advantages, and thereby improve corporate re-entrepreneurial performance. This also finds support in the study of Luo et. al., who hold that political connections can efficiently affect government policies, the formulation of laws and regulations and companies' acquiring entrepreneurial resources, and thereby help companies gain competitive advantages [106]. This finding enables us to further understand the acquisition of entrepreneurial resources. Thirdly, institutional environment plays a positive moderating role in the relationship between political connections and corporate re-entrepreneurial performance. One of the characteristics of transition economies is the uncertainty of entrepreneurial environment confronting companies, especially the political environment. By analyzing the sample data, this study finds that the more dynamic institutional environment, the greater impacts political connections have on corporate re-entrepreneurial performance and the same applies in reverse. Peng et al. also discovered that policy support for entrepreneurship has noticeable impacts on corporate re-entrepreneurial performance [17]. The finding of our study also provides supplement to the research result of Liu et al. that institutional environment can influence the relationship between political connections and corporate performance [58].

The main theoretical contributions of this study are as follows. Firstly, this study explores the influence factors of corporate re-entrepreneurship under the background of transitional economy from the resource-based view and the institution-based view, which enriches research into the antecedent causes of corporate re-entrepreneurship as well as expanding the application range of the theory of political connections. Secondly, resource acquisition is introduced as the mediating variable and institutional environment as the moderating role to establish a research framework of political connections, resource acquisition, institutional environment, and corporate re-entrepreneurship, revealing the internal action mechanism of political connections on corporate re-entrepreneurship. In addition, this study provides theoretical reference for companies expecting to build competitive advantages in the fiercely competitive market environment.

Compared with previous studies which investigated entrepreneurship from the perspectives of entrepreneurial teams and entrepreneurial opportunities, the study differs in the way that it empirically examines for the first time the internal influence mechanism of different types of political connections on corporate re-entrepreneurial performance from the perspective of political connections, which helps us better understand the driving factors behind corporate re-entrepreneurial performance.

The research results indicate that there is close relationship among political connections, acquisition of entrepreneurial resources, and corporate re-entrepreneurial performance, which is a significant discovery for corporate re-entrepreneurship. Acquisition of entrepreneurial resources is included in the study of the relationship between political connections and corporate re-entrepreneurial performance, which is not only a beneficial supplement to research into the antecedent variables of acquisition of entrepreneurial resources but provides a new path for improving corporate re-entrepreneurial performance. Meanwhile, it is a rewarding attempt to include institutional environment as the moderating variable in the conceptual framework of the study and illustrate the significant effects of institutional factor on the improvement of corporate re-entrepreneurial performance from another perspective.

\subsection{Management Implications}

Political institution and entrepreneurship have been hot topics in academia, and this study provides helpful implications for corporate re-entrepreneurship, especially in the context of transition economy 
from the perspective of political connections. Firstly, political connections as a significant influence factor in re-entrepreneurship decision and implementation should be taken into consideration in the process of corporate re-entrepreneurship. Companies should consider the various impacts of political connections on corporate re-entrepreneurship and the coping strategies in combination with their practical situation rather than taking it for granted that political connections will surely promote corporate re-entrepreneurial performance. Secondly, companies should attach great significance to other factors that influence corporate re-entrepreneurial performance, especially corporate network capability. Under the current circumstances of complicated and changeable social network, network capability has become a key approach to acquiring the necessary resources for corporate re-entrepreneurship. Companies can actively learn the knowledge and skills needed for re-entrepreneurship through their external network ties, and seek and accumulate favorable asset resources to establish competitive advantages and promote re-entrepreneurial performance. Thirdly, changes in the external institutional environment cannot be neglected. Institutional environment, which is an important part of corporate re-entrepreneurial environment and closely related to corporate re-entrepreneurial activities, have obvious impacts on corporate re-entrepreneurial performance. Therefore, companies should pay close attention to the external institutional environment and adjust their re-entrepreneurial strategies in accordance with the changes of institutional environment. In this way, they can optimize re-entrepreneurial implementation path and means and gain competitive advantages at the institutional level.

Even though previous studies as well as our study have shown that political connections have positive impacts on corporate re-entrepreneurial performance, the risks involved cannot be neglected. First, political connections are not necessarily beneficial to the improvement of corporate performance. In other words, they might have negative impacts on it. The difference between marginal revenue and marginal cost of political connections determines the direction and range of the changes of corporate performance [122]. If marginal revenue is less than marginal cost, corporate performance is negatively affected. Additionally, political connections make companies undertake more social responsibilities, which in turn increases substantially corporate political cost and consequently decreases corporate value [123]. Scholars such as Bertrand and Fan discovered that political connections have negative impacts on corporate performance through their follow-up studies of enterprises in different countries [124,125], which requires that companies should attach great importance to the potential risks of political connections during the process of re-entrepreneurship. Secondly, the action mechanism of political connections is influenced and restricted by many factors. When companies try to establish political connections, they must cope with the direct effects of market environment and legal institutions, and private companies also must face the discrimination because of their private ownership [126]. Meanwhile, the changes of political environment and government officials also affect corporate political connections and as a result affect to varying degrees corporate re-entrepreneurial performance via political connections. Accordingly, companies must try to avoid the disadvantageous impacts of external environment when improving re-entrepreneurial performance by means of political connections [127].

Author Contributions: Conceptualization, Z.W.; Data curation, Q.L.; Formal analysis, Z.W.; Investigation, Z.W.; Methodology, X.L.; Project administration, X.L.; Resources, Z.W. and Q.L.; Software, Q.L.; Supervision, X.L.; Writing-Original draft, Z.W.; Writing-Review and editing, X.L.

Funding: This research received no external funding.

Conflicts of Interest: The authors declare no conflict of interest. 


\section{Appendix A}

Table A1. Rotated Component Matrix.

\begin{tabular}{cccccc}
\hline \multirow{2}{*}{ Factors } & \multicolumn{5}{c}{ Components } \\
\cline { 2 - 6 } & $\mathbf{1}$ & $\mathbf{2}$ & $\mathbf{3}$ & $\mathbf{4}$ & $\mathbf{5}$ \\
\hline a1 & 0.291 & 0.306 & 0.233 & 0.127 & 0.808 \\
a2 & 0.326 & 0.222 & 0.179 & 0.291 & 0.787 \\
a3 & 0.303 & 0.242 & 0.824 & 0.270 & 0.218 \\
a4 & 0.345 & 0.259 & 0.831 & 0.216 & 0.200 \\
a5 & 0.313 & 0.802 & 0.318 & 0.206 & 0.222 \\
a6 & 0.382 & 0.754 & 0.196 & 0.255 & 0.304 \\
a7 & 0.404 & 0.753 & 0.196 & 0.313 & 0.242 \\
a8 & 0.413 & 0.353 & 0.372 & 0.680 & 0.263 \\
a9 & 0.445 & 0.366 & 0.315 & 0.657 & 0.278 \\
a10 & 0.426 & 0.373 & 0.324 & 0.680 & 0.263 \\
a16 & 0.792 & 0.294 & 0.150 & 0.315 & 0.199 \\
a17 & 0.827 & 0.239 & 0.254 & 0.257 & 0.218 \\
a18 & 0.855 & 0.252 & 0.266 & 0.164 & 0.230 \\
a19 & 0.794 & 0.309 & 0.145 & 0.304 & 0.193 \\
a20 & 0.834 & 0.240 & 0.252 & 0.249 & 0.200 \\
a21 & 0.856 & 0.258 & 0.249 & 0.176 & 0.230 \\
a22 & 0.852 & 0.257 & 0.256 & 0.163 & 0.248 \\
\hline
\end{tabular}

Table A2. Path coefficients of CFA.

\begin{tabular}{ccccc}
\hline Items & Estimate & S.E. & Est./S.E. & $p$-Value \\
\hline Explicit political connections & & & & \\
a1 & 0.869 & 0.025 & 34.482 & 0.000 \\
a2 & 0.894 & 0.024 & 37.504 & 0.000 \\
Implicit political connections & & & & \\
a3 & 0.960 & 0.012 & 79.058 & 0.000 \\
a4 & 0.963 & 0.012 & 79.932 & 0.000 \\
Acquisition of entrepreneurial knowledge resources & & & & \\
a5 & 0.924 & 0.012 & 77.737 & 0.000 \\
a6 & 0.927 & 0.012 & 78.997 & 0.000 \\
a7 & 0.951 & 0.009 & 101.290 & 0.000 \\
a8 & & & & \\
a9 & 0.984 & 0.004 & 271.334 & 0.000 \\
a10 & 0.960 & 0.006 & 156.736 & 0.000 \\
Acquisition of entrepren & 0.967 & 0.005 & 182.477 & 0.000 \\
a16 & & & & \\
a17 & & & \\
a18 & 0.845 & 0.019 & 43.933 & 0.000 \\
a19 & 0.907 & 0.012 & 75.834 & 0.000 \\
a20 & 0.995 & 0.001 & 1029.823 & 0.000 \\
a21 & 0.847 & 0.019 & 44.412 & 0.000 \\
a22 & 0.909 & 0.012 & 77.046 & 0.000 \\
Corporate re-entrepren & 0.989 & 0.002 & 576.627 & 0.000 \\
& 0.995 & 0.001 & 1065.883 & 0.000 \\
\hline
\end{tabular}

\section{References}

1. Antoncic, B.; Hisrich, R.D. Clarifying the intrapreneurship concept. J. Small Bus. Enterp. Dev. 2003, 10, 7-24. [CrossRef]

2. Javalgi, R.G.; Hall, K.D.; Cavusgil, S.T. Corporate entrepreneurship, customer-oriented selling, absorptive capacity, and international sales performance in the international B2B setting: Conceptual framework and research propositions. Int. Bus. Rev. 2014, 23, 1193-1202. [CrossRef]

3. Bloodgood, J.M.; Hornsby, J.S.; Burkemper, A.C.; Sarooghi, H. A system dynamics perspective of corporate entrepreneurship. Small Bus. Econ. 2015, 45, 383-402. [CrossRef] 
4. Chua, J.H.; Chrisman, J.J.; Sharma, P. Defining the family business by behavior. Entrep. Theory Pract. 1999, 23, 19-39. [CrossRef]

5. Kuratko, D.F.; Audretsch, D.B. Clarifying the domains of corporate entrepreneurship. Int. Entrep. Manag. J. 2013, 9, 323-335. [CrossRef]

6. Serai, M.H.; Johl, S.K.; Marimuthu, M. Conceptual framework of sustainable corporate Entrepreneurship. In Proceedings of the International Symposium on Technology Management and Emerging Technologies (ISTMET), Langkawai Island, Malaysia, 25-27 August 2015; IEEE: Piscataway, NJ, USA, 2015; pp. 432-436.

7. Abosede, J.A.; Fayose, J.; Eze, B.U. Corporate entrepreneurship and international performance of Nigerian banks. J. Econ. Manag. 2018, 32, 5-17. [CrossRef]

8. Covin, J.G.; Miles, M.P. Corporate entrepreneurship and the pursuit of competitive advantage. Entrep. Theory Pract. 1999, 23, 47-63. [CrossRef]

9. Zahra, S.A.; Covin, J.G. Contextual influences on the corporate entrepreneurship-performance relationship: A longitudinal analysis. J. Bus. Ventur. 1995, 10, 43-58. [CrossRef]

10. Hayton, J.C. Promoting corporate entrepreneurship through human resource management practices: A review of empirical research. Hum. Resour. Manag. Rev. 2005, 15, 21-41. [CrossRef]

11. Hornsby, J.S.; Kuratko, D.F.; Shepherd, D.A.; Bott, J.P. Managers' corporate entrepreneurial actions: Examining perception and position. J. Bus. Ventur. 2009, 24, 236-247. [CrossRef]

12. Ireland, R.D.; Covin, J.G.; Kuratko, D.F. Conceptualizing corporate entrepreneurship strategy. Entrep. Theory Pract. 2009, 33, 19-46. [CrossRef]

13. Zhang, X.; Li, J. Research on the differences of key factors and functional mechanism between first venture and second venture: Match among opportunities, resources and capacities. R D Manag. 2012, 12, 116-125.

14. McEnany, R.; Strutton, D. Leading the (r) evolution: Succession and leadership rules for re-entrepreneurs. Bus. Horiz. 2015, 58, 401-410. [CrossRef]

15. He, Y.Q.; Pan, J.Y. A multi-case analysis of the influencing factors of re-entrepreneurial performance. Stud. Sci. Sci. 2018, 36, 1432-1441.

16. Plehn-Dujowich, J. A theory of serial entrepreneurship. Small Bus. Econ. 2010, 35, 377-398. [CrossRef]

17. Peng, H.T.; Xu, Q.; Zhang, J.J.; Yu, Y.B. A research on the mechanism of market orientation and policy orientation on choice of the second entrepreneurial path for enterprises in traditional industries. Sci. Res. Manag. 2018, 39, 56-66.

18. Kuratko, D.F.; Hornsby, J.S.; Hayton, J. Corporate entrepreneurship: The innovative challenge for a new global economic reality. Small Bus. Econ. 2015, 45, 245-253. [CrossRef]

19. Feng, X.; Johansson, A.C.; Zhang, T. Mixing business with politics: Political participation by entrepreneurs in China. J. Bank. Financ. 2015, 59, 220-235. [CrossRef]

20. Simsek, Z.; Lubatkin, M.H.; Floyd, S.W. Inter-firm networks and entrepreneurial behavior: A structural embeddedness perspective. J. Manag. 2003, 29, 427-442.

21. Cai, L.; Ge, B.S.; Zhu, X.M.; Fei, Y.P.; Liu, Q. Establishing the frame of entrepreneurial research based on resource view. China Ind. Econ. 2007, 11, 96-103.

22. Li, X.L.; Ma, S.; Deng, X. Family of civil servants, entrepreneurship and rent-seeking motivation. Econ. Res. J. 2015, 5, 89-103.

23. Chen, K.; Hillman, A.L.; Gu, Q.Y. Fiscal re-centralization and behavioral change of local government: From the helping hand to the grabbing hand. China Econ. Q. 2002, 2, 111-130.

24. Firth, M.; Lin, C.; Liu, P.; Wong, S.M. Inside the black box: Bank credit allocation in China's private sector. J. Bank. Financ. 2009, 33, 1144-1155. [CrossRef]

25. Li, H.; Meng, L.; Wang, Q.; Zhou, L.A. Political Connections and Firm Performance: Evidence from Chinese Private Firms; Unpublished Working Paper; Chinese University of Hong Kong: Hong Kong, China, 2005.

26. Peng, M.W. Towards an institution-based view of business strategy. Asia Pac. J. Manag. 2002, 19, $251-267$. [CrossRef]

27. Wu, J.J. An Empirical Research on the Relationship between Enterprises' Political Connections and Firm Performance; Jilin University: Changchun, China, 2018.

28. Faccio, M. Politically connected firms. Am. Econ. Rev. 2006, 96, 369-386. [CrossRef]

29. Krueger, A.O. The political economy of the rent-seeking society. Am. Econ. Rev. 1974, 64, 291-303.

30. Fisman, R. Estimating the value of political connections. Am. Econ. Rev. 2001, 91, 1095-1102. [CrossRef] 
31. Goldman, E.; Rocholl, J.; So, J. Do politically connected boards affect firm value? Rev. Financ. Stud. 2008, 22, 2331-2360. [CrossRef]

32. Schoenherr, D. Political connections and allocative distortions. J. Financ. Forthcom. 2018. [CrossRef]

33. Xu, Y.J.; Miao, S. The Study on the Impact of political connection on the performance of cross-border mergers and acquisitions. IJAME 2019, 8, 11-23.

34. Hersch, P.; Netter, J.M.; Pope, C. Do campaign contributions and lobbying expenditures by firms create "political" capital? Atl. Econ. J. 2008, 36, 395-405. [CrossRef]

35. Hillman, A.J. Politicians on the board of directors: Do connections affect the bottom line? J. Manag. 2005, 31, 464-481. [CrossRef]

36. Rajwani, T.; Liedong, T.A. Political activity and firm performance within nonmarket research: A review and international comparative assessment. J. World Bus. 2015, 50, 273-283. [CrossRef]

37. Li, S. Research on the Relationship between Entrepreneurship Resources and Entrepreneurial Performance Based on Strategic Perspective; Jilin University: Changchun, China, 2014.

38. Coombes, S.M.T.; Morris, M.H.; Allen, J.A.; Webb, J.W. Behavioural orientations of non-profit boards as a factor in entrepreneurial performance: Does governance matter? J. Manag. Stud. 2011, 48, 829-856. [CrossRef]

39. Carmona, P.; Momparler, A.; Gieure, C. The performance of entrepreneurial small-and medium-sized enterprises. Serv. Ind. J. 2012, 32, 2463-2487. [CrossRef]

40. Wu, S.Y.; Wang, D.; Wang, B.; Li, X.Y. Research on the influence mechanism of incubator network on the entrepreneurship performance of high level talents. Stud. Sci. Sci. 2016, 34, 1680-1688.

41. Schmitt, B. Experiential marketing. J. Mark. Manag. 1999, 15, 53-67. [CrossRef]

42. Jiang, D.K. Researches on the Relationships between Proactive-Orientation and Entrepreneurial Performance under Different Industry Pressure: Based on Functions of Entrepreneurial Strategy and Relationship Networks; Jilin University: Changchun, China, 2017.

43. Wall, T.D.; Michie, J.; Patterson, M.; Wood, S.J. On the validity of subjective measures of company performance. Pers. Psychol. 2004, 57, 95-118. [CrossRef]

44. Saikhan, B. Research on the Relationship among Entrepreneurial Environment, Entrepreneurial Orientation and Enterprise Performance of Mongolian SMEs; Jilin University: Changchun, China, 2014.

45. Yu, S.Z. The Effect of Entrepreneurial Resource and Entrepreneurial Strategy on Entrepreneurial Performance: Based on Moderating Mechanism of Environment and Organization Structure; Zhejiang University: Hangzhou, China, 2012.

46. Liedong, T.A. Corporate Political Activity and Firm Performance-A Systematic Review. Available online: http://dspace.lib.cranfield.ac.uk/handle/1826/8065 (accessed on 3 March 2018).

47. Maaloul, A.; Chakroun, R.; Yahyaoui, S. The effect of political connections on companies performance and value: Evidence from Tunisian companies after the revolution. J. Account. Emerg. Econ. 2018, 8, 185-204. [CrossRef]

48. Li, J.; Xia, J.; Zajac, E.J. On the duality of political and economic stakeholder influence on firm innovation performance: Theory and evidence from Chinese firms. Strateg. Manag. Rev. 2018, 39, 193-216. [CrossRef]

49. Cheng, L.; Cheng, H.; Zhuang, Z. Political connections, corporate innovation and entrepreneurship: Evidence from the China Employer-Employee Survey (CEES). China Econ. Rev. 2018, 54, 286-305. [CrossRef]

50. Cheng, W.; Wu, Y. Bank finance for private firms in China: Does political capital still pay off? World Econ. 2019, 1, 242-267. [CrossRef]

51. Claessens, S.; Feijen, E.; Laeven, L. Political connections and preferential access to finance: The role of campaign contributions. J. Financ. Econ. 2008, 88, 554-580. [CrossRef]

52. Hu, F.; Leung, S. Appointment of Political Top Executives and Subsequent Performance and Corporate Governance: Evidence from China's Listed SOEs. 2009. Available online: https://papers.ssrn.com/sol3/ papers.cfm?abstract_id=1361617 (accessed on 18 March 2009).

53. Yan, R.S.; Jiang, X. The multiple relationship model and empirical research of institutional environment, political connections, financing constraints and R\&D investment. Chin. J. Manag. 2019, 16, 72-84.

54. Pan, X.; Tian, G.G. Bank work experience versus political connections: Which matters for bank loan financing? Int. Rev. Financ. 2018. [CrossRef]

55. Zhang, T.S.; Chen, X.Y.; Huang, J. Political connection, venture capital and firm performance. Nankai Bus. Rev. 2015, 5, 18-27. 
56. Hadani, M.; Schuler, D.A. In search of El Dorado: The elusive financial returns on corporate political investments. Strateg. Manag. Rev. 2013, 34, 165-181. [CrossRef]

57. Lee, W.; Wang, L. Do political connections affect stock price crash risk? Firm-level evidence from China. Rev. Quant. Financ. Account. 2017, 48, 643-676. [CrossRef]

58. Liu, H.; Yang, J.Y.; Augustine, D. Political ties and firm performance: The effects of proself and prosocial engagement and institutional development. Glob. Strateg. J. 2018, 8, 471-502. [CrossRef]

59. Caves, R.E. Industrial organization, corporate strategy and structure. In Readings in Accounting for Management Control; Springer: Boston, MA, USA, 1980; pp. 335-370.

60. Barney, J. Firm resources and sustained competitive advantage. J. Manag. 1991, 17, 99-120. [CrossRef]

61. Grande, J.; Madsen, E.L.; Borch, O.J. The relationship between resources, entrepreneurial orientation and performance in farm-based ventures. Entrep. Reg. Dev. 2011, 23, 89-111. [CrossRef]

62. Zhou, R.H. A Review of Related Theoretical Research on Entrepreneurial Resource Acquisition. Manag. Technol. SME 2017, 36, 95-96.

63. Sirmon, D.G.; Hitt, M.A.; Ireland, R.D. Managing firm resources in dynamic environments to create value: Looking inside the black box. Acad. Manag. Rev. 2007, 32, 273-292. [CrossRef]

64. Cai, L.; Zhu, X.M.; Liu, Y. An research on entrepreneurial performance of venture firm: From the respective of trust between entrepreneur and venture capitalist. Stud. Sci. Sci. 2011, 29, 601-609.

65. Baker, T.; Nelson, R.E. Creating something from nothing: Resource construction through entrepreneurial bricolage. Adm. Sci. Q. 2005, 50, 329-366. [CrossRef]

66. Villanueva, J. Does It Matter How You Tell It? On How Entrepreneurial Storytelling Affects the Opportunity Evaluations of Early-Stage Investor; University of Minnesota: Minneapolis, MN, USA, 2012.

67. Luo, X.P. Research on the Influence of Entrepreneurial Narrative on the Resources Acquistion under the Background of "Mass Entrepreneurship and Innovation"; University of Science and Technology of China: Hefei, China, 2018.

68. Florin, J.; Lubatkin, M.; Schulze, W. A social capital model of high-growth ventures. Acad. Manag. J. 2003, 46, 374-384.

69. Shane, S.; Cable, D. Network ties, reputation, and the financing of new ventures. Manag. Sci. 2002, 48, 364-381. [CrossRef]

70. Putnam, R.D.; Leonardi, R.; Nanetti, R.Y. Making Democracy Work: Civic Traditions in Modern Italy; Princeton University Press: Princeton, NJ, USA, 1994.

71. Wang, Z.; Liu, X. Study on the Influence of Political Connections on Real Estate Firms' Starting Business Ventures-With Resource Acquisition Playing an Intermediary Role. In World Conference on Management Science and Human Social Development (MSHSD); Atlantis Press: Paris, France, 2017.

72. Premaratne, S.P. Networks, resources, and small business growth: The experience in Sri Lanka. J. Small Bus. Manag. 2001, 39, 363-371. [CrossRef]

73. Heirman, A.; Clarysse, B. How and why do research-based start-ups differ at founding? A resource-based configurational perspective. J. Technol. Transf. 2004, 29, 247-268. [CrossRef]

74. Dou, H.B.; Wang, Z.B. An empirical study on social capital's impact to enterprise innovation performanc: The intermediary role of knowledge resources acqusition. Forecast 2011, 30, 48-52.

75. Feng, C.L.; Zhang, M.Y.; Liu, H.T.; Zhang, H.; He, M. Research on the relationship between supply chain knowledge sharing and firm performance: The mediating and moderating effect of supply chain agility and environmental dynamics. Manag. Rev. 2015, 27, 181-191.

76. Mustafa, M.J.; Hughes, M. The Kenyan Environment's Influence on the Emergence and Development of Corporate Entrepreneurship among SMEs. In African Entrepreneurship; Palgrave Macmillan: Cham, Switzerland, 2018; pp. 59-88.

77. Nadkarni, S.; Barr, P.S. Environmental context, managerial cognition, and strategic action: An integrated view. Strateg. Manag. J. 2008, 29, 1395-1427. [CrossRef]

78. Jiao, H.; Zhou, J.H.; Xie, Z.D. The empirical study on the relationship between entrepreneurial orientation and firm's performance: Based on the moderating effect of environmental dynamism. Sci. Sci. Manag. S. T. 2001, 11, 70-76.

79. Cooper, M.J.; Gulen, H.; Ovtchinnikov, A.V. Corporate political contributions and stock returns. J. Financ. 2010, 65, 687-724. [CrossRef]

80. Adhikari, A.; Derashid, C.; Zhang, H. Public policy, political connections, and effective tax rates: Longitudinal evidence from Malaysia. J. Account. Public Policy 2006, 25, 574-595. [CrossRef] 
81. Li, H.B.; Meng, L.; Wang, Q.; Zhou, L.A. Political connection, financing and firm performance: Evidence from Chinese private firms. J. Dev. Econ. 2008, 87, 283-299. [CrossRef]

82. Wang, Z.Y. Political Relevance and Technological Innovation in Small and Medium-Sized High-Tech Enterprises: Theoretical Model and Empirical Analysis; China University of Political Science and Law Press: Beijing, China, 2014.

83. Yu, H.; Nahm, A.Y.; Song, Z. Guanxi, political connections and resource acquisition in Chinese publicly listed private sector firms. Asia Pac. Bus. Rev. 2017, 23, 336-353. [CrossRef]

84. Yu, M.G.; Hui, Y.F.; Pan, H.B. Political connections, rent-seeking and the effectiveness of local government financial subsidies. Econ. Res. J. 2010, 3, 65-77.

85. Li, W.A.; Xu, Y.K. The effect of political identity on tax avoidance. J. Financ. Res. 2013, 3, 114-129.

86. Wang, B.; Yan, S.; Wang, L. Resource dependence or monitoring: A governance perspective on political connections. Asia-Pac. J. Account. Econ. 2019, 1-26. [CrossRef]

87. Song, M.; Ai, H.; Li, X. Political connections, financing constraints, and the optimization of innovation efficiency among China's private enterprises. Technol. Forecast. Soc. Chang. 2015, 92, 290-299. [CrossRef]

88. Kung, J.K.; Ma, C. Friends with benefits: How political connections help to sustain private enterprise growth in China. Economica 2018, 85, 41-74. [CrossRef]

89. Li, S.M.; Zhao, J.J.; Liu, Y. Industry opportunities, political connection and diversification by M\&A. China Manag. Stud. 2009, 4, 1-17.

90. Chung, C.Y.; Byun, J.H.; Young, J. Corporate political ties and firm value: Comparative analysis in the Korean Market. Sustainability 2019, 11, 327. [CrossRef]

91. Xin, K.K.; Pearce, J.L. Guanxi: Connections as substitutes for formal institutional support. Acad. Manag. J. 1996, 39, 1641-1658.

92. Yang, Y.; Ning, X.D. Political connections, government subsidies and corporate innovative performance. Technol. Econ. 2018, 37, 34-40.

93. Zhu, X.M.; Li, M.F. The dynamic impact of the entrepreneurial network on the resource acquisition: An evidence based on China's transitional economy. Manag. World 2011, 6, 105-116.

94. Hu, X.Y.; Wu, Y.P. Study on transgenerational transfer of political capital of Chinese family firm-An empirical analysis based on entrepreneurs' membership of PC or CPPCC. China Ind. Econ. 2016, 1, 146-160.

95. Madhok, A. Reassessing the fundamentals and beyond: Ronald Coase, the transaction cost and resource-based theories of the firm and the institutional structure of production. Strateg. Manag. J. 2002, 23, 535-550. [CrossRef]

96. Degong, M.; Ullah, F.; Khattak, M.S.; Anwar, M. Do international capabilities and resources configure firm's sustainable competitive performance? Research within Pakistani SMEs. Sustainability 2018, 10, 4298. [CrossRef]

97. Shane, S.A. A General Theory of Entrepreneurship: The Individual-Opportunity Nexus; Edward Elgar Publishing: Cheltenham, UK, 2003.

98. Lee, K.; Choo, K.; Yoon, M. Comparing the productivity impacts of knowledge spillovers from network and arm's length industries: Findings from business groups in Korea. Ind. Corp. Chang. 2015, 25, 407-427. [CrossRef]

99. Anwar, M.; Khan, S.Z.; Khan, N.U. Intellectual capital, entrepreneurial strategy and new ventures performance: Mediating role of competitive advantage. Bus. Econ. Rev. 2018, 10, 63-93. [CrossRef]

100. Barney, J.B.; Arikan, A.M. The resource-based view: Origins and implications. Handb. Strateg. Manag. 2001, $5,124-188$.

101. Leuz, C.; Oberholzer-Gee, F. Political relationships, global financing, and corporate transparency: Evidence from Indonesia. J. Financ. Econ. 2006, 81, 411-439. [CrossRef]

102. Zhang, J.J.; Zhang, Z.X. Political strategies of private entrepreneurs in China. Manag. World 2005, 7, 94-105.

103. Lei, G.Y.; Li, S.F.; Wang, X.J. Political connections, choice of auditors and corporate value. Manag. World 2009, 7, 145-155.

104. Yu, M.G.; Pan, H.B. Political connections, institutional environment and private enterprises' bank loans. Manag. World 2008, 8, 9-21.

105. Agrawal, A.; Knoeber, C.K. Do Some Outside Directors Play a Political Role? J. Law Econ. 2001, 44, $179-198$. [CrossRef] 
106. Khwaja, A.I.; Mian, A. Do lenders favor politically connected firms? Rent provision in an emerging financial market. Q. J. Econ. 2005, 120, 1371-1411. [CrossRef]

107. Johnson, S.; Mitton, T. Cronyism and capital controls: Evidence from Malaysia. J. Financ. Econ. 2003, 67, 351-382. [CrossRef]

108. Luo, D.L.; Liu, X.L. Political relationship, barriers to entry and enterprises' performance: Evidence from China's private listed companies. Manag. World 2009, 5, 97-106.

109. Li, Z.J. Research Prospects of Strategic Transition of Real Estate Enterprises. China Manag. Inf. 2018, 21, 97-98.

110. Su, X.J. Ten innovation directions of the present real estate industry. Hous. Real Estate 2016, 2, $27-32$.

111. Morck, R.; Wolfenzon, D.; Yeung, B. Corporate governance, economic entrenchment, and growth. J. Econ. Lit. 2005, 43, 655-720. [CrossRef]

112. Li, H.G.; Cao, Y.Y.; Du, Y.Z. Corporate innovational strategic response under dynamic institutional environment. Chin. J. Manag. 2018, 15, 71-79.

113. Marquis, C.; Qian, C. Corporate social responsibility reporting in China: Symbol or substance. Organ. Sci. 2014, 25, 127-148. [CrossRef]

114. Zhang, X.J.; Guo, L. The mechanism, channels and strategies of political connections: Based on the research of Chinese private enterprises. Financ. Trade Econ. 2019, 9, 99-104.

115. Wang, Q.W.; Wu, S.N. Impacts of political connections on firm performance: Based on study of political influence indexes of China's listed companies. In Proceedings of the Papers of the Seventh International Symposium on Empirical Accounting in China, Chengdu, China, 20-21 December 2008.

116. Pfeffer, J.; Salancik, G.R. The External Control of Organizations: A Resource-Dependence Perspective; Standford University Press: Palo Alto, CA, USA, 2003.

117. Murphy, G.B.; Trailer, J.W.; Hill, R.C. Measuring performance in entrepreneurship research. J. Bus. Res. 1996, 36, 15-23. [CrossRef]

118. Luo, S.Q.; Jiang, Y. Management Survey Research Methodology; Chongqing University Press: Chongqing, China, 2014.

119. Li, H.Z. Research Methodology for Management; Xi'an Jiaotong University Press: Xi'an, China, 2000.

120. Baron, D.P. Integrated strategy, trade policy and global competition. Calif. Manag. Rev. 1997, 39, $145-169$. [CrossRef]

121. Song, X.Y.; Peng, L. Political connections, diversified strategies and firm performance: An empirical study of listed private companies in Zhejiang Province. Friends Account. 2015, 18, 48-52.

122. Shleifer, A.; Vishny, R. Politician and Firms. Q. J. Econ. 1994, 109, 995-1025. [CrossRef]

123. Faccio, M.; Lang, L.H.P. The Ultimate Ownership of Western European Corporations. J. Financ. Econ. 2002, 65, 365-395. [CrossRef]

124. Bertrand, M.; Kramarz, F.; Schoar, A.; Thesmar, D. Politicians, Firms and Political Business Cycle: Evidence from France; Working Paper; University of Chicago: Chicago, IL, USA, 2006.

125. Fan, J.P.H.; Wong, T.J.; Zhang, T.Y. Political-connected CEOs, corporate governance and post-IPO performance of China's newly partially privatized firms. J. Financ. Econ. 2007, 84, 330-357. [CrossRef]

126. Hu, X.Y. Political Connections and Competitive Advantages of Private Enterprises: Based on the Perspective of Strategic Management; Zhejiang University Press: Hangzhou, China, 2013.

127. Luo, D.L.; Tang, Q.Q. Study on the institutional environment and performance of China's private listed companies. Econ. Res. J. 2009, 2, 106-118.

(C) 2019 by the authors. Licensee MDPI, Basel, Switzerland. This article is an open access article distributed under the terms and conditions of the Creative Commons Attribution (CC BY) license (http://creativecommons.org/licenses/by/4.0/). 